\title{
The Holmes Truth: Toward a Pragmatic, Holmes- Influenced Conceptualization of the Nature of Truth
}

\author{
Jared Schroeder* \\ Southern Methodist University, Dallas, Texas
}

\begin{abstract}
Truth as a fundamental ingredient within the flow of discourse and the application of freedom of expression in democratic society has historically received considerable attention from the U.S. Supreme Court. Many of the Court's central precedents regarding First Amendment concerns have been determined by how justices have understood truth and how they have conceptualized the complex relationship truth and falsity share. Despite the attention truth has received, however, the Court has not provided a consistent understanding of its meaning. For these reasons, this article examines how the Supreme Court has conceptualized truth in freedom-of-expression cases, ultimately drawing upon the results of that analysis, as well as pragmatic approaches to philosophy, the so called "pragmatic method" put forth by American philosopher William James, to propose a unifying conceptualization of truth that could be employed to help the Court provide consistency within its precedents regarding the meaning of a concept that has been central to the Court's interpretation of the First Amendment since, in many ways, another pragmatist and friend of James's, Justice Oliver Wendell Holmes, substantially addressed truth in his dissent in Abrams v. United States. The article concludes by proposing that the courts conceptualize the nature of truth via three substantially related understandings: that truth is a process, that it is experiencefunded, and that it is not absolute and is best approached without prejudice. Each of the three ingredients relates, at least to some extent, with thematic understandings put forth by the Court in previous freedom-of-expression cases, and therefore does not represent a significant departure from justices' traditional approaches to truth. The model, most ideally, does seek, with the help of pragmatic thought and ideas put forth by Justice Holmes, to encourage consistent recognition of certain principles regarding truth as justices go about considering its nature in First Amendment cases.
\end{abstract}

\section{KEYWORDS}

First Amendment; Truth; Pragmatism; Holmes; Supreme Court.

\section{CONTENTS}

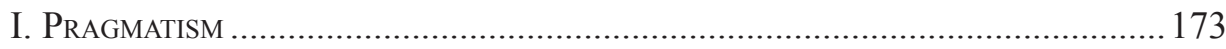

A. Pragmatism as Method............................................................. 174

B. Toward Pragmatically Discerned Truth ....................................... 176

* Jared Schroeder is an assistant professor of journalism at Southern Methodist University in Dallas, Texas. He is the author of The Press Clause and Digital Technology's Fourth Wave. 


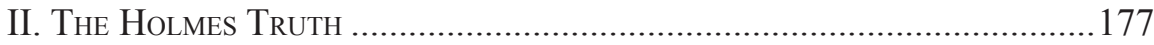

A.The Mirage of Absolute Truth .......................................................177

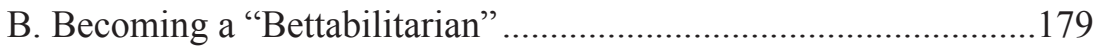

C. Labor and Socialist Unrest...........................................................180

D. The Unpublished Dissent .............................................................181

E. The Three Sedition Cases .............................................................182

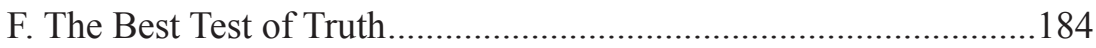

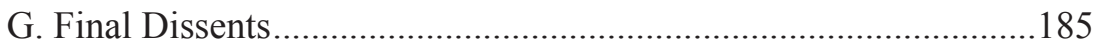

III. TRuth AND the Court After Holmes ..................................................187

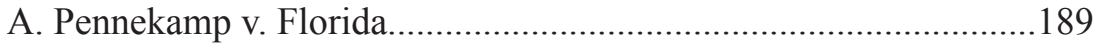

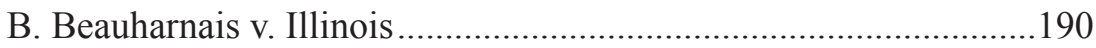

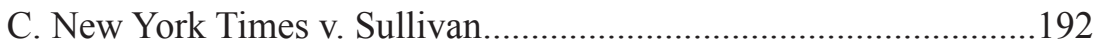

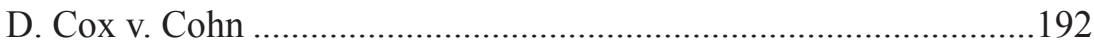

E. Philadelphia Newspapers v. Hepps …………………………........193

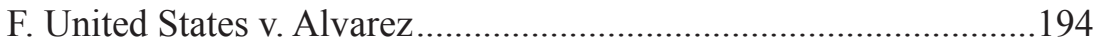

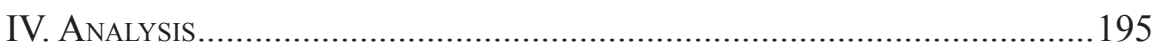

A. The Value of Free Debate as a Public Good ………....................195

B.The Provisional and Contingent Nature of "Truth" .......................197

C. Communication as a Social Process...............................................199

V. Proposing a Unified Conceptualization of Truth ...............................201 
The concept of truth as an integral component in the exercise of discourse and freedom of expression in democratic society has historically received considerable attention from the Supreme Court. Many of the Court's pivotal decisions regarding First Amendment concerns have been determined by how justices have conceptualized truth and how they have understood the complex connection truth and falsity share in free debate. ${ }^{1}$ Concerns regarding truth and protections for truthful statements have received so much attention that it would be easy to conclude that the matter is settled - the First Amendment in nearly all instances protects truthful statements. Such a conclusion, however, only identifies the central role of truth in discourse. It does not address the question of how justices have understood truth or the nature of truth in the sense that how justices conceptualize what truth is, in a philosophical sense, will influence how the Court rules within a variety of areas of First Amendment law. The lack of clarity regarding the nature of truth within the Court's jurisprudence, despite there being a relatively clear protection for truthful statements, can be compared with the statement that the First Amendment does not protect obscene content. ${ }^{2}$ The Court has consistently upheld this conclusion, though the challenge of defining what constitutes obscenity persists. ${ }^{3}$ Similarly, the Court has consistently emphasized the centrality of truth in communication in democratic society, but has not provided a consistent understanding of its meaning.

Importantly, consistently identifying that the First Amendment protects truthful speech is not the same as exploring the Court's philosophical conceptualizations regarding the meaning of truth in an effort to both identify the reasons that justices have used to rationalize conclusions in truth-focused cases and to consider a potentially unifying model for how justices could understand truth, thus potentially providing greater consistency in their rulings. ${ }^{4}$ After all, the Court has constructed tests in areas such as threatening speech toward the government, ${ }^{5}$ obscenity, ${ }^{6}$ and advertising regulation, ${ }^{7}$ for example, but has not constructed a consistent approach to evaluating matters of truth and falsity, and their merits as contributors to communication in a democratic society. Such a concern has been highlighted

See Abrams v. United States, 250 U.S. 616 (1919); Near v. Minnesota, 283 U.S. 697 (1931); Thornhill v. Alabama, 310 U.S. 88 (1940); Chaplinsky v. New Hampshire, 315 U.S. 568 (1942); Dennis v. United States, 341 U.S. 494 (1951); Burstyn v. Wilson, 343 U.S. 1952; Roth v. United States, 354 U.S. 476 (1957); New York Times v. Sullivan, 376 U.S. 254 (1964); Columbia Broadcasting System v. Democratic Nat'l Committee, 412 U.S. 94 (1973); Cox v. Cohn, 420 U.S. 469 (1975); Hustler v. Falwell, 485 U.S. 46 (1988) for examples.

2 Miller v. California, 413 U.S. 15 (1973).

3 Cass Sunstein, Pornography and the First Amendment, 1986 Duke L.J. 589, 591-593 (1986). Prior to the Miller Test, Justice Potter Stewart expressed his frustration with defining obscenity when he wrote, "I shall not today attempt to further define the kinds of material I understand to be embraced within that shorthand description and perhaps I could never succeed intelligibly doing so. But I know it when I see it," Jacobellis v. Ohio, 378 U.S. 184, 197 (1964) (Stewart, J., concurring).

4 Alexander M. Bickel, The Least Dangerous Branch: The Supreme Court at the Bar of Politics 112 (1962); James H. Fowler \& Sangick Jeon, The Authority of Supreme Court Precedent, 30 Social Networks 16, 16 (2008).

Brandenburg v. Ohio, 395 U.S. 444 (1969).

Miller v. California, 413 U.S. 15 (1973).

Central Hudson Gas \& Electric v. Public Service Comm., 447 U.S. 557 (1980). 
in relatively recent decisions as justices have devoted portions of opinions to justifications of protections of truth and reciprocal concerns regarding falsity. ${ }^{8}$ Whilst justices have ardently defended the rights of individuals to communicate truthful statements, whether writing the opinion of the Court, a concurrence, or a dissent, they have at times disagreed widely regarding the nature of truth. In United States v. Alvarez for example, justices disagreed substantially regarding the Stolen Valor Act, a law that criminalized false statements about having earned military honors. Justice Samuel Alito, in a dissent that was joined by two other justices, concluded false claims such as those made by Xavier Alvarez, "possess no intrinsic First Amendment value" and therefore should not be protected. ${ }^{9}$ Justice Anthony Kennedy, writing for the Court, framed truth as something that develops through discourse, concluding, "society has a right and civic duty to engage in open, dynamic, rational discourse." 10 The ways that the two justices understood the nature of truth influenced their positions in the case's outcome. Justice Kennedy referred to an emergent form of truth, subjective and the result of experience. Justice Alito referred to a more universal form of truth, pre-existent and absolute.

The Court has traditionally focused justifications for interpreting the First Amendment as protecting certain forms of truthful or less-than-truthful speech, rather than taking the additional step of addressing the nature of truth as it applies to fostering communication in a democratic society. For these reasons, this article examines how the Supreme Court has conceptualized truth in freedomof-expression cases, and then draws on the results of that analysis, as well as pragmatic approaches to philosophy, the so called "pragmatic method" put forth by American philosopher William James, ${ }^{11}$ to propose a unifying conceptualization of truth that could be employed to help the Court provide consistency within its precedents regarding the meaning of a concept that has been central to the Court's interpretation of the First Amendment since, in many ways, another pragmatist and friend of James's, Justice Oliver Wendell Holmes, substantially addressed truth in his dissent in Abrams v. United States. ${ }^{12}$ The pragmatic method is uniquely suited for such an enquiry because its approach emphasizes practical investigation of how the world is understood because, as James lamented during the lectures in which he laid out the pragmatic ideal in 1906, too much of philosophy "bakes no bread."13 Pragmatism also avoids philosophical extremes, instead approaching each problem with "the attitude of looking away from first things, principles, categories, supposed necessities; and of looking towards things, fruits, consequences, facts." ${ }^{14}$ Finally, pragmatism is uniquely suited to questions regarding freedom of expression. Judge Richard Posner contended "There is at least one specific legal question to which

8 See Reed v. Town of Gilbert, 135 S. Ct. 2218 (2015); United States v. Alvarez, 132 S. Ct. 2537 (2012); Snyder v. Phelps, 562 U.S. 443 (2011) for examples.

9 Alvarez, 132 S. Ct. at 2560 (Alito, J., dissenting).

10 Id. at 2550.

11 William James, Pragmatism 28-29 (1978).

12 Abrams v. United States, 250 U.S. 616 (1919). See The Essential Holmes: Selections from the Letters, Speeches, Judicial Opinions and Other Writings of Oliver Wendell Holmes, JR. xi (Richard A. Posner ed., 1992) and Louis Menand, The Metaphysical Club: A Story of IdeAs IN AMERICA x-xi (2002) for Holmes's relationship to pragmatic thought.

13 JAMES, supra note $11,10$.

$14 \quad I d$. at 32 . 
pragmatism is directly applicable and that is the question of the basis and extent of the legal protection of free speech." 15

In many ways, Justice Holmes laid much of the groundwork for a pragmatic method for understanding truth in the Abrams dissent in 1919, both by drawing pragmatic thought into the Court's narrative concerning freedom of expression and by introducing the marketplace-of-ideas metaphor into the Court's lexicon. ${ }^{16}$ The metaphor, which is substantially rooted in communicating how Justice Holmes understood the nature of truth, is cited in dozens of freedom-of-expression-related case in which justices have wrestled with matters of truth in falsity. ${ }^{17}$ As a result, this article begins and ends with Justice Holmes at the forefront. This article first examines the American pragmatic movement, outlining the assumptions its adherents made regarding the nature of truth, before considering Justice Holmes's extensive and often philosophical writings outside of the Court, as well as his foundational freedom-expression-related legal opinions. After outlining pragmatic thinking and examining Justice Holmes's understandings regarding the nature of truth, six of the cases in which the Court has most incorporated the word "truth" in regard to freedom-of-expression concerns ${ }^{18}$ are analyzed using sociologist David Altheide's method for qualitative document analysis with the goal of identifying how justices in the decades since Justice Holmes's retirement and the eventual fading of pragmatic thought from American discourse have articulated how they understand the nature of truth. ${ }^{19}$ In drawing central conceptual building blocks from American pragmatic thought, Justice Holmes's writings outside of the Court and his opinions for the Court, and themes from cases in which truth has been a central point of contention among the justices, this article concludes by proposing a unifying, pragmatics-based approach to the nature of truth that is specific to the Court and the role of freedom of expression in a democratic society.

\section{Pragmatism}

While James is the figure most closely associated with the formation of American pragmatic philosophy, it was his friend Charles Sanders Peirce who coined the term "pragmatism." 20 Peirce, an American philosopher and mathematician, joined

15 Richard A. Posner, What Has Pragmatism to Offer Law?, 63 S. CAL. L. Rev. 1653, 1661 (1989).

16 Id. at 1662. Judge Posner, for example, found that the pragmatic approach is a "plausible extension" of the marketplace-of-ideas metaphor.

17 See Walker v. Tex. Div., Sons of Confederate Veterans, 135 S. Ct. 2239 (2015); Milkovich v. Lorain Journal, 497 U.S. 1 (1990); Texas v. Johnson, 491 U.S. 397 (1989); Miami Herald v. Tornillo, 418 U.S. 241 (1974); and Tinker v. Des Moines, 393 U.S. 503 (1969) for examples.

18 The cases were identified by conducting a search in the WestlawNext database for all the cases dealing with the First Amendment and the word "truth." The cases were ranked based on the number of times justices used the word "truth" in the case opinions.

19 David L. Altheide, Qualitative Media Analysis 16 (1996). Information regarding case selection and the method of analysis is provided later in the study.

20 JAMES, supra note 11, at vii. James stated pragmatism was "oddly named," see JAMES, supra note 11, at 23. 
James and Holmes, along with other intellectuals in Cambridge, Mass., to form what became known as the Metaphysical Club in early $1870 \mathrm{~s} .{ }^{21}$ While the group was short-lived, it operated during a period in which the minds of three great American thinkers intersected to discuss philosophical concerns of the day. ${ }^{22}$ In 1872, during one of the final meetings of the Metaphysical Club, Peirce read a paper that espoused support for a pragmatic form of belief that operated as a way of scientifically conceptualizing chance and uncertainty in the universe.$^{23}$ A revised version of that paper, published six years later in Popular Science Monthly under the title "How to Make Our Ideas More Clear," stands as the origin of American pragmatic thought. ${ }^{24}$ Peirce contended that the way individuals consider truth or meaning is based on guesses that are educated by past personal experience. James and Holmes, who was then the editor of The American Law Review, supported such an experience-oriented view of how individuals understand and interact with the world around them. ${ }^{25}$ Years later, in 1900, Peirce wrote to his old friend James to ask him who coined the term "pragmatism." James responded, "You invented pragmatism, for which I gave you full credit." 26

\section{A. PRAGMatism as METHOD}

Peirce coined the term "pragmatism," but it was James, late in his life, who gave it definition and form as a discernable philosophical approach and who made it a topic of conversation within and without the scholarly community. In 1898, he delivered a lecture titled "the Pragmatic Method," at the University of California, in which he outlined what would become his lasting, influential contribution to philosophy. ${ }^{27}$ During the lecture, James contended "To develop a thought's meaning we need only determine what conduct it is fitted to produce; that conduct is for us its sole significance." ${ }^{28}$ Such an approach foreshadowed his later work in devising a pragmatic method. James retired from Harvard in 1907, starting a brief period (he died in 1910) during which he was most focused on pragmatism and philosophy

21 Menand, supra note 12, at 216, 226.

22 It could be stated that the Metaphysical Club was pre-dated by the Saturday Club in Cambridge, Massachusetts, which included Oliver Wendell Holmes Sr. and Benjamin Peirce, Charles's Harvard-professor father, as well as Ralph Waldo Emerson, who was close friends with Henry James, William James's father, and an early inspiration to Oliver Wendell Holmes Jr. The club also included Louis Agassiz, who Henry James went on an expedition of South America with. See Menand, supra note 12, at x-xi, at 17 and 83 and Richard Ormerod, The History and Ideas of Pragmatism, 57 THE J. OF THE OPERATIONAL Research Soc. 892, 895 (2006).

23 Menand, supra note 12, at 227.

24 Charles Sanders Peirce, How to Make Our Ideas Clear, in The Nature of Truth: Classic and Contemporary Perspectives 193-209 (Michael P. Lynch, ed., 2001); James B. Pratt, What is Pragmatism? 16-17 (1909).

25 Menand, supra note 12, at 229.

26 Joseph Brent, C.S. PeirCe: A Life 86 (1998).

27 Richard J. Bernstein, The Pragmatic Turn 1-2 (2010).

28 William James, The Pragmatic Method, 1 J. of Philosophy \& Scientific Methods 673, 673 (1904). 
more generally. ${ }^{29} \mathrm{He}$ turned a series of lectures he gave in Boston and New York that year into Pragmatism, the foundational work for American pragmatic thought. James identified his aim in formulating a pragmatic method when he concluded that much of modern philosophy accomplishes nothing of practical use or importance. ${ }^{30}$ In the place of such thought, James outlined the pragmatic method as a sort of tool for getting to the practical truth that is in contention within any substantial dispute regarding ideas. The method begins by asking a simple question, which James repeated throughout Pragmatism: "What difference would it practically make to anyone if this notion rather than that notion were true?" ${ }^{31}$ If there is no practical difference, he contended, there is no meaningful dispute. Therefore, philosophic discussion should focus on finding "what definite difference it will make to you and me, at definite instances of our life, if this world-formula or that world-formula be the true one." ${ }^{32}$ In this sense, James's method was ideally suited to discussion of the meaning of truth and to resolving exactly the types of conflicts the Supreme Court must rule upon.

The next step in the pragmatic method, then, is, in the presence of actual conflict regarding truth or a set of issues, to clear away any considerations that do not practically matter to the outcome. James explained that a pragmatic thinker "turns away from abstraction and insufficiency, from verbal solutions, from bad a priori reasons, from fixed principles, closed systems, and pretended absolutes and origins. He turns towards concreteness and adequacy, towards facts, towards action, and towards power." ${ }^{33}$ James's words convey his disagreement with much of science in the early twentieth century. In his view, scientific theories were being misused because they were seen as solutions rather than tools, answers rather than lenses. ${ }^{34}$ A central aspect of the pragmatic method was to avoid coming to a conclusion based solely on "fixed principles." 35 Thus, the method, from this point, focused on identifying what the truth and the truth's "cash-value" meaning was in practical terms. James explained:

\footnotetext{
Pragmatism, on the other hand, asks its usual question. 'Grant an idea or belief be true,' it says, 'what concrete difference will its being true make in anyone's actual life?' 'How will the truth be realized?' 'What existences will be different from those which would obtain if the belief were false?' 'What, in short, is the truth's cash-value in experiential terms?'36
}

It is at this truth-evaluating stage of the method that James's contribution to philosophy, and this article, most principally defined itself.

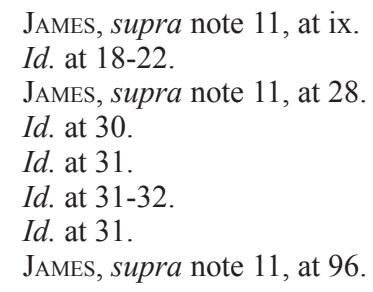




\section{B. TOWARD PRAGMATICALLY DISCERNED TRUTH}

James characterized pragmatism as both a method and a theory of truth, and in many ways the two are inseparable because the method does not function without an explanation of James's conceptualization of truth. ${ }^{37}$ Perhaps James's most important, and complex, contribution in his articulation of the pragmatic method is his discussion of the nature of truth and how individuals in a democratic society should determine its meaning. James did not believe in a universal, objective truth. ${ }^{38}$ He recognized that all do not share a single reality regarding the world around them. ${ }^{39}$ In relation to this matter, he contended that individuals use their experiences to determine what is true. As a person encounters information in his or her daily life, he or she does not stop to verify each item. Instead, people rely on a bank of experiences, which collect to form reality. James conceptualized truth as "a collective name for verification processes, just as health, wealth, and strength, etc., are names for other processes connected with life, and also pursued because it pays to pursue them. Truth is made, just as health, wealth and strength are made, in the course of experience." ${ }^{\prime 40}$ Individuals verify information by comparing it to the reality they have formed as a result of their experiences. In this model, truth is simply anything that aligns with an individual's reality.

Such a notion of truth has been criticized for its fluidity, ${ }^{41}$ but this was a feature James, and later pragmatic thinkers who followed him, such as John Dewey and Richard Rorty, embraced..$^{42}$ It is also related to Justice Holmes's conceptualization of truth in the sense that both opposed absolute idealism..$^{43}$ At the outset, James contended that pragmatism "unstiffens all our theories, limbers them up." 44 When truth is "experience funded," ${ }^{45}$ it allows individuals the flexibility to revise their understandings as new information and new experiences arise. In this sense, James understood each person as continually taking in ideas. Most ideas would be accepted or rejected based on a person's reality. ${ }^{46}$ Some ideas, however, have the power to shift a person's reality; they became part of that internal accumulation and constant evaluation of the world around

37 John J. Stuhr, 100 Years of Pragmatism: Williams James's Revolutionary Philosophy 2 (2010).

8 JAMES, supra note 11, at 116.

$39 \quad$ Id.

$40 \quad I d$. at 104.

41 Josiah Royce, James's colleague at Harvard, was a critic of James's conceptualization of truth. Royce believed in a unity of truth that is shared by all. See JosiaH Royce, The Religious Aspect of Philosophy: A Critique of the Bases of Conduct and of Faith 423-25 (1885). See also James Conant, The James/Royce Dispute and the Development of James's "Solution," in the Cambridge Companion to William James 187-88 (Ruth Anna Putnam, ed., 1997).

42 Colin Koopman, Pragmatism as a Philosophy of Hope: Emerson, James, Dewey, Rorty, J. Speculative Philo. 106, 110-111 (2006); Richard Rorty, Contingency, Irony, and Solidarity 26-27 (1993); John Dewey, The Development of American Pragmatism, in The Essential Dewey Vol. 1, 8 (Larry A. Hickman \& Thomas M. Alexander, eds.).

43 Bernstein, supra note 27, at 61; Menand, supra note 12, at 66; The Essential Holmes supra note 12, at 115-16.

44 JAMES, supra note 11, at 32.

$45 \quad I d$. at 107.

46 Id. at 97-99. 
them. This is what was meant when James concluded that ideas do not lead people to the truth, instead "truth happens to an idea." ${ }^{47} \mathrm{He}$ wrote that:

\begin{abstract}
The truth of an idea is not a stagnant property inherent in it. . . It becomes true, is made true by events. Its verity is in fact an event, a process: the process namely of its verifying itself, its verification. Its validity is the process of its validation. ${ }^{48}$
\end{abstract}

Such a perspective is substantially similar to Justice Holmes's thesis in The Common Law in 1881 that "The life of the law has not been logic: it has been experience." 49 Truth, in the conceptualization of the pragmatic method, is derived from the collection of experiences that make up an individual's reality. It is verified by that reality and subject to change based on shifts in how an individual understands the world.

\title{
II. The Holmes Truth
}

Justice Holmes is included in discussions of pragmatism and at times ascribed the pragmatist label because ideas he communicated in his writings and his relationships with the man who named the philosophy, Peirce, and the man who defined and explained it, James. ${ }^{50}$ Justice Holmes did not understand himself, however, to be a pragmatist. In a letter, late in his life, he separated himself from pragmatism, admonishing his friend to avoid the term unless he meant that he followed James's philosophy. He wrote, "I could never make anything out of his or his friends' advocacy of his nostrum. . . I think as little of his philosophy as I do much of his psychology. He seems to me typical Irish in his strength and his weakness." ${ }^{51}$ The letter was written in 1917, seven years after James's funeral, which Justice Holmes attended. Such references indicate that Justice Holmes, late in his life, might not have thought much of James or his philosophy, but he did think of him. Several of Justice Holmes's letters mention James, long after his friend had died. ${ }^{52}$ At one time, early in their lives, during the Metaphysical Club era, the two appeared to be close in their thinking, but aside from foundational agreements that overlap with pragmatism's basic assumptions, their views diverged. ${ }^{53}$

\section{A.The Mirage of AbSOlute Truth}

On a basic level, Holmes agreed with James regarding the subjective, personal nature of truth, and the role experience plays in determining how individuals

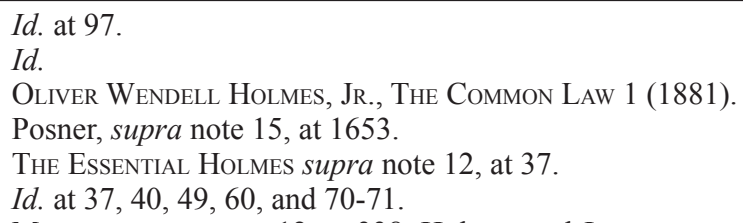


understand the world around them. In a letter to a friend in 1912, seven years before he would introduce the marketplace metaphor in his dissent in Abrams v. United States,${ }^{54}$ Justice Holmes explained:

\begin{abstract}
A general fact rather is to be regarded like a physical phenomenon accepted like any other phenomenon so far as it exists - to be combated or got around so far as may be, if one does not like it, as soon as fully possible. I always say yes - whatever is, is right - but not necessarily will be for thirty seconds longer..$^{55}$
\end{abstract}

Justice Holmes's personal correspondences include many such references to the subjectivity of information individuals consider to be true. ${ }^{56}$ In a letter in 1929 , for example, he concluded, "absolute truth is a mirage." ${ }^{57}$ Years earlier, in his law article Natural Law, the jurist dismissed absolute truth as a product of the natural human desire to be certain. ${ }^{58} \mathrm{He}$ famously found, "Certitude is not the test of certainty. We have been cock-sure of many things that were not so." ${ }^{59}$ Holmes's conceptualization of truth, however, developed differently than other traditional pragmatists, a detail that is also characterized in Natural Law. ${ }^{60}$ Unlike James, and Peirce for that matter, Holmes fought in the Civil War and his experiences in which, scholars posit, influenced how he viewed the development of truth and the necessity for debate in democratic society. ${ }^{61}$

Scholars have suggested that Holmes entered the war an idealist, joining the Army during his final year at Harvard because of his abolitionist views. He left the battlefields skeptical of those who held rigid, absolutist views about the world around them. ${ }^{62}$ In the decades that followed the war, Holmes often used the word "experience" in his descriptions of how the war changed him and others. He stated in his Memorial Day speech in 1884 that "the generation that carried on the war has been set apart by its experience. Through our great good fortune, in our youth our hearts were touched with fire." ${ }^{63}$ In a speech to veterans in 1897, he expressed how the war gave him "a different feeling to life." ${ }^{64} \mathrm{He}$ further lamented his experiences with death during the Civil War in a letter to a friend in 1911. In the letter, Justice Holmes recalled the recent passage of the fiftieth anniversary of his first wounds in the Civil War, and noted that earlier that day he had heard of his colleague, Justice John Harlan's death. He commented that the war had accustomed him to death when he was young. ${ }^{65}$ The first injury Holmes referred to in the letter was

250 U.S. 616 (1919).

The Essential Holmes supra note 12, at 7.

Id. at $107,115,117$, for example.

Id. at 107.

Oliver Wendell Holmes, Natural Law, 32 Harv. L. Rev. 40, 40-41 (1918).

Id. at 40 .

Id. at 41-42.

Menand, supra note 12, at 64-66; Catherine Wells Hantzis, Legal Innovation - the Wider Intellectual Tradition: The Pragmatism of Oliver Wendell Holmes, Jr., 82 Nw. U. L. Rev. 541, 548 (1987).

62 Mark DeWolfe Howe, The Positivism of Mr. Justice Holmes, 64 Harv. L. Rev. 529, 535 (1951); Menand, supra note 12, at 38.

63 Oliver Wendell Holmes, Speeches 11 (2006).

64 The Essential Holmes, supra note 12, at 73.

$65 \quad I d$. at 3. 
a gunshot wound to the chest at Ball's Bluff in Virginia in $1861 .{ }^{66}$ The doctors told him he would likely die from the wound and, at 20 years old, Holmes was left to face death. ${ }^{67}$ After he survived, he wrote in his journal that he considered it "curious how rapidly the mind adjusts itself under some circumstances to entirely new relations. ${ }^{\circ 68}$ He wrote that when he thought he was going to die, it seemed a natural thing, but when he learned he would live, the thought of dying again became unconscionable ${ }^{69}$ Cultural historian Louis Menand contended that during experiences and reciprocal reflections such as this during the war, Holmes recognized that a person's beliefs, even foundational ones about life and death, were contingent on experience. ${ }^{70}$ Perspectives change as a result of experience, an idea that, whether Holmes would have found the comparison agreeable or not, aligns quite closely with James's position that "new truth is always a go-between, a smoother-over of transitions. It marries old opinion."

\section{B. BECOMING A "BETTABILITARIAN"}

On a broader scale, the simmering tensions between North and South that ultimately resulted in the war instilled an understanding in Holmes that rigid, unmoving certainty about truth is likely to lead to violence. ${ }^{72}$ Both Northerners and Southerners viewed their positions as absolutely right, and that unwavering posture led to a war in which Holmes saw several of his friends killed and was himself shot three different times. ${ }^{73} \mathrm{He}$ used war imagery to communicate this idea in Natural Law, in which he argued that "we all, whether we know it or not, are fighting to make the kind of world we should like - but that we have learned to recognize that others will fight and die to make a different world, with equal sincerity and belief." 74 In the same passage, Justice Holmes concluded, "When differences are sufficiently far reaching, we try to kill the other man rather than let him have his way. But that is perfectly consistent with admitting that, so far as it appears, his grounds are just as good as ours." 75 Such a central passage in Justice Holmes's scholarly writing, published in the year prior to his authorship of the marketplace metaphor in Abrams, further illuminates his unique, but also pragmatically founded, approach toward absolute positions. His experiences made him more skeptical of certainty and those who claimed to be certain about the truths they believed. In this regard, late in his life, Justice Holmes declared himself a "bettabilitarian," which he explained as a person who does not believe in the possibility of absolute certainty, but does expect that he can bet, using the experiences that have formed his reality,

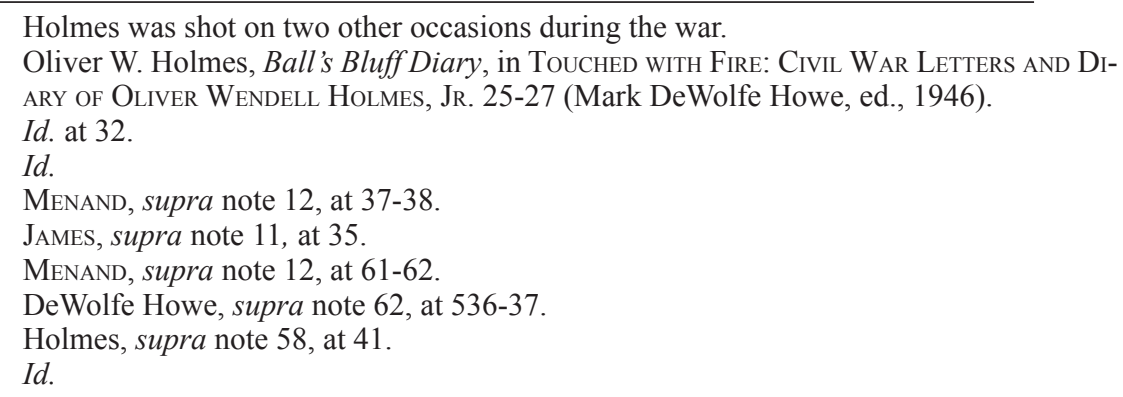


on "the behavior of the universe in its contact with us." attributed the "bettabilitarian" idea's foundation to Chauncey Wright, a member of the Metaphysical Club who died in $1875 .{ }^{77}$ Holmes referred to himself in such light from 1915 to 1930, most often during a lengthy correspondence with American philosopher Morris Cohen. ${ }^{78}$ When discussing the term with Cohen, Justice Holmes often referred to himself as having his own "universe," within the context of each person forming his or her own reality. ${ }^{79}$ Legal scholar David Luban described Justice Holmes's "bettabilitarian" terminology as reinforcing his consistent claim that individuals base their knowledge of the world around them on a "leap of faith rather than a reasoned demonstration." $" 80$

Justice Holmes's rejection of absolute positions, and his position that the best anyone can do is "bet" on what the truth is, extended to his judicial philosophy and interactions with other justices. ${ }^{81}$ In a letter to a friend in 1920, he explained that he does not believe cases can be settled by general propositions. To support his position, he wrote that he made it a practice to challenge the other justices to choose any general legal philosophy and he would create a reason why the case could be decided on those grounds. ${ }^{82}$ Such a perspective is consistent with Justice Holmes's central premise in The Common Law, which he wrote in 1881 . He famously contended that the "life of the law has not been logic: it has been experience. ${ }^{.83} \mathrm{He}$ elaborated on the statement by contending that the passage of time, the development of political theories, public policy decisions, the prejudices of judges, and other influences have had a greater impact on legal decisions than logic. ${ }^{84}$ Mark DeWolfe Howe, who clerked for Justice Holmes and became his biographer, concluded that Holmes's statement about the life of the law was a form of rejection of the traditionalist approach to the law and to "purely logical - even theological - methods which threatened to dominate legal thought." ${ }^{\circ 5}$ In this sense, Justice Holmes's statement that the law is based on experience ideally surmises the substantially pragmatic assumptions Justice Holmes developed and applied throughout his life.

\section{LABOR AND SOCIALIST UNREST}

Unprecedented labor unrest in the 1890s and governmental concern regarding the spread of socialism during and after World War I placed Justice Holmes in a unique position to substantially shape the foundations of First Amendment

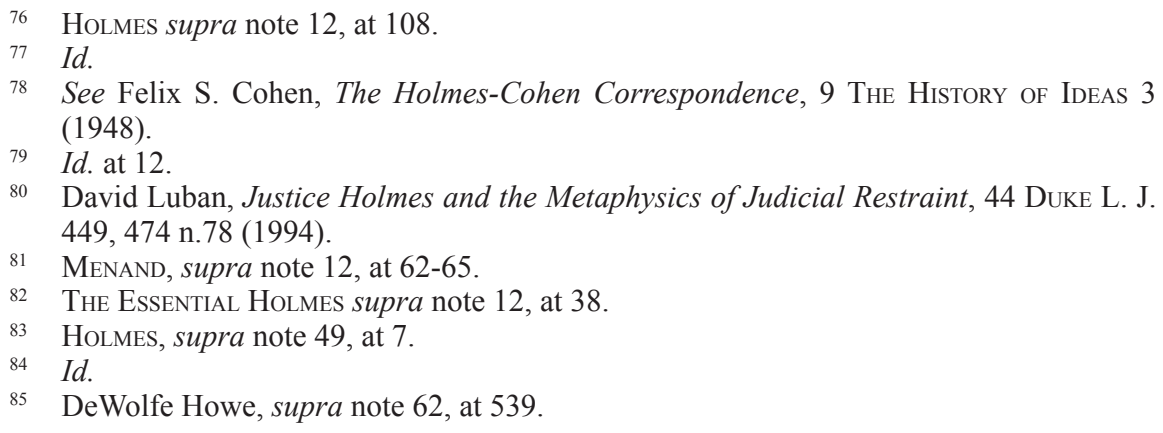


jurisprudence during the heart of his career as a jurist. ${ }^{86}$ Justice Holmes, raised as part of the New England elite, did not think much of labor unionists or socialism. ${ }^{87}$ In a letter in 1912, before the wave of cases regarding socialist activities began to reach the Supreme Court, Justice Holmes wrote to a friend that he had read several central works about socialism and found it to be "wrongly thought." ${ }^{88} \mathrm{He}$ further determined "I have as little enthusiasm for it as I have for teetotalism." 89 Justice Holmes, however, read Karl Marx, Georg Wilhelm Friedrich Hegel, Herbert Spencer, and others in trying to understand organized labor and socialism. ${ }^{90}$ Such an approach was evident in three dissents Justice Holmes penned during his final years on the Massachusetts Supreme Judicial Court. In each case he sided with organized labor, those who picketed or refused to work, in an effort to improve wages. In particular, in Vegelahn v. Gunter, an 1896 case involving a worker strike at a furniture manufacturer's business, Justice Holmes contended that part of free competition allows for competitive interference to a person's business, whether the source of interference is a new, competing business or workers using their power to receive a wage increase..$^{1}$ He continued, "The only debatable ground is the nature of the means by which damage is inflicted." ${ }^{92} \mathrm{He}$ dissented in a similar case four years later, finding that the conflict between two disagreeing groups must "be carried out in a fair and equal way." ${ }^{93}$ Interestingly, without specifically invoking freedom of expression protections, on the state or federal level, Justice Holmes came to a conclusion that expression should be protected, but only up to the point that it causes or substantially threatens violence or injury.

\section{THE UNPUBLISHED DISSENT}

Such cases clearly set the stage for the ten-year period, from 1919 to 1929 , when Justice Holmes, at that point a veteran of the Supreme Court, added First Amendment considerations to the ideas he developed about protections for expression while on Massachusetts's highest court. Before the well-known stream of sedition cases arose, starting with Schenck v. United States in 1919, the Court heard arguments in Baltzer v. United States in November 1918, just as the armistice ending World War I was being signed. ${ }^{94}$ During the war, Emanuel Baltzer and two dozen other socialists wrote letters to the governor of South Dakota demanding changes to the draft system. They threatened to vote the governor out of office if such changes

86 Sheldon M. Novick, The Unrevised Holmes and Freedom of Expression, 1991 Sup. Ст. Rev. 303, 303 (1991).

87 Novick, supra note 86, at 315; Plant v. Woods, 176 Mass. 492, 505 (Mass. 1900) (Holmes, C. J., dissenting); The Essential Holmes supra note 12, at 30.

88 The Essential Holmes supra note 12, at 66.

89 Id.

90 Novick, supra note 86 , at 314.

91167 Mass. 92, 106 (Mass. 1896) (Holmes, J., dissenting).

92 Id.

93 Plant v. Woods, 176 Mass. 492, 504 (Mass. 1900) (Holmes, C. J., dissenting).

94 Baltzer v. United States, 248 U.S. 593 (1918). The decision cited here merely notes that there was an error in the government's case, which led to the case being returned to the lower court. 
were not made..$^{95}$ They were arrested and charged for violating the Espionage Act of 1917 because their letters were interpreted as an effort to obstruct the draft. The Court voted 7-2 to uphold the convictions, with Justices Holmes and Louis Brandeis opposing the decision. Justice Holmes contended in his dissent that "our intention to put all our powers in aid of success in war should not hurry us into intolerance of opinions and speech that could not be imagined to do harm." ${ }^{96} \mathrm{He}$ concluded that the Court should "err on the side of freedom" and "that the emergency would have to be very great before I could be persuaded that an appeal for political action through legal channels, addressed to those supposed to have power to take such action was an act that the Constitution did not protect." 97 Justice Holmes's dissent was not popular with Chief Justice Edward White, who sought the strength of a unanimous court. He delayed the announcement of the opinion, which proved to be fortuitous when the government admitted an error in its work in the case and it was remanded for retrial, thus leaving Justice Holmes's dissent unpublished. ${ }^{98}$

\section{E. THE THREE SEDITION CASES}

The unpublished dissent in Baltzer represented the first time Justice Holmes explicitly incorporated First Amendment principles into what he had already been developing as an approach to freedom of expression that allowed the free exchange of ideas, as long as there was no real threat of injury to others. ${ }^{99}$ The dissent also came just months after he published Natural Law, in which he articulated his skepticism of absolutist perspectives and questioned those who contend truth is fixed and universal. ${ }^{100}$ His developing ideas regarding freedom of expression were tested in the Court's next term, however. When the Court returned to work in January 1919, three new cases involving the Espionage Act of 1917 awaited the justices. ${ }^{101}$ All of the cases involved socialists who were convicted for their anti-war statements. Justice Holmes wrote short, terse opinions that upheld the convictions under the act for a unanimous court in all three of the cases. The outcomes of the cases, on the surface, appear to be in direct conflict with Holmes's conclusions in the labor union cases from the 1890s and the unpublished Baltzer dissent a few months earlier. In each case, however, Justice Holmes emphasized a pragmatically related principle that aligns closely with his conclusions regarding the

\footnotetext{
Novick, supra note 86 , at 331 .

$96 \quad I d$. at 332. Since the dissent was never published, the only record of the text was found in Justice Holmes's personal papers. As a result, see also Thomas Healy, The Justice Who Changed His Mind: Oliver Wendell Holmes, Jr., and the Story Behind Abrams v. United States, 39 J. Sup. Ст. Hist. 35, 43-44 (2014), for a second source regarding the non-published dissent's wording.

98 Novick, supra note 86, at 333.

99 See Commonwealth v. Perry, 155 Mass. 117 (Mass. 1891) (Holmes, J., dissenting); Vegelahn v. Guntner, 167 Mass. 92 (1896) (Holmes, J., dissenting); Plant v. Woods, 176 Mass. 492 (1900) (Holmes, C. J., dissenting).

100 Holmes, supra note 58, at 40-41.

101 Schenck v. United States, 249 U.S. 47 (1919); Frohwerk v. United States, 249 U.S. 204 (1919); and Debs v. United States, 249 U.S. 211 (1919). Sugarman v. United States, 249 U.S. 182 (1919) presented a similar question to the Court but was dismissed because it presented no constitutional question.
}

$97 \quad I d$. 
nature of truth and his rejection of absolute positions. His decisions were based on the context of the person's actions. He explained in Schenck that "in ordinary times the defendants in saying all that was said ... would have been within their constitutional rights. But the character of every act depends upon the circumstances in which it is done." 102 Thus, the dispersal of an anti-draft message during World War I by Charles Schenck, as general secretary of the Socialist Party in Philadelphia, had effectively pushed the messages outside of the purview of First Amendment protection. Justice Holmes supported his contention with the example that freedom of speech does not protect a person's right to cause a panic by falsely yelling "fire" in a crowded theater and concluded by introducing the clear and present danger test. ${ }^{103}$ Similarly, in the case of Jacob Frohwerk's Missouri Staats Zeitung newspaper's anti-war messages in 1917, Justice Holmes concluded that "the First Amendment, while prohibiting legislation against free speech as such cannot have been, and obviously was not, intended to give immunity for every possible use of language." 104 In both examples, as well as in Debs $v$. United States during the same term, Justice Holmes rejected an absolute protection for freedom of expression, thus reinforcing his distrust of absolutist positions found in his letters and legal scholarship. ${ }^{105}$

Despite his apparently confident reasoning in the opinions, Justice Holmes was not at complete peace with the outcomes. In a letter to Harold Laski, then a Harvard professor and dear friend, a week after the Frohwerk and Debs decisions were announced, Holmes wrote "I greatly regretted having to write them - and (between ourselves) that the government pressed them to a hearing. ... But on the only questions before us I could not doubt about the law."106 Justice Holmes went on to express his discomfort with the number of convictions lower-court judges were upholding in regard to speech and the war. ${ }^{107}$ About a year later, Laski was gone from Harvard, having been largely pressured to leave because of his socialist views. ${ }^{108}$ Upon learning the news, Justice Holmes lamented his friend's departure, "Dear lad, I shall miss you sadly. There is no other man I should miss so much."109

Justice Holmes's decision to join the Court and write its opinions upholding Espionage Act convictions that ultimately limited expression in three cases during the spring of 1919 caught the attention of leading thinkers, such as Laski, Zechariah Chafee, and Judge Learned Hand. ${ }^{110}$ During the summer that followed, Judge Hand approached Justice Holmes, whom he revered, in person and followed that meeting with a letter regarding the three sedition rulings. ${ }^{111}$ Judge Hand, as a federal district judge in New York, had constructed a different approach to similar cases in 1917, basing his ruling on the question of whether the speakers' expressions were a "direct incitement." 112 His test, which was overturned on appeal, substantially narrowed the

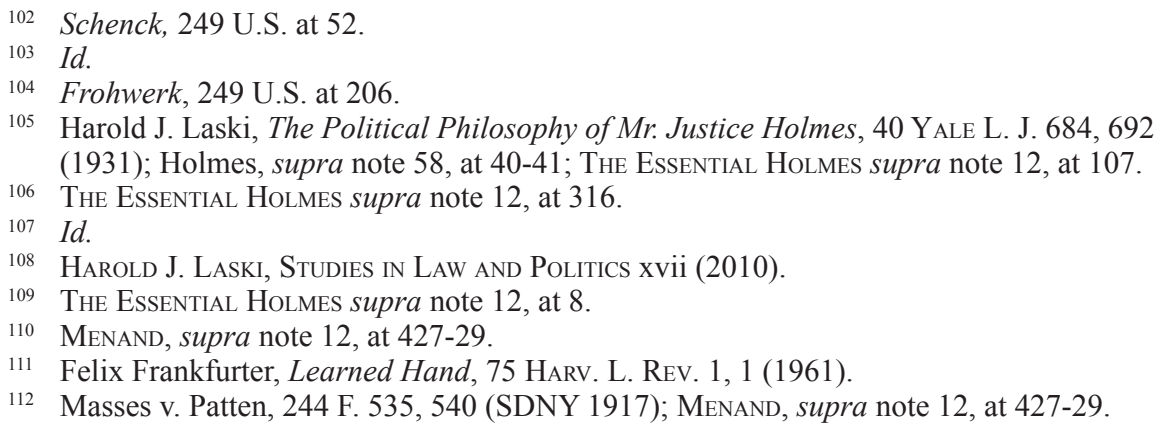


field of speech that could be prosecuted under the Espionage Act. Justice Holmes flatly disagreed with him, contending it was the context of the action, not the words themselves, which should be the deciding factor. ${ }^{113}$

\section{F. THE BEST TEST OF TRUTH}

Abrams was waiting for the justices when they returned to work in the fall of 1919 . Much as with the cases from the previous term, Jacob Abrams and others spread ideas that were critical of the war effort, this time in July 1918, not long before the war's end. ${ }^{114}$ Seven justices voted to uphold Abrams's twenty-year prison sentence for violating the Espionage Act, but Justice Holmes indicated he would dissent. Three justices went to his house in an effort to convince him to change his vote so that the Court could remain unanimous in matters relating to the Red Scare. ${ }^{115}$ Justice Holmes was not deterred, ultimately writing a dissent that amounts to his most complete statement regarding truth as it relates to freedom of expression. ${ }^{116}$ The dissent includes all of the central characteristics of Justice Holmes's tendency toward pragmatic thought. He concluded that, "When men have realized that time has upset many fighting faiths, they may come to believe even more than they believe the very foundations of their own conduct that the ultimate good desired is better reached by free trade in ideas." 117 Within the passage, he drew from his understanding that experience shapes reality and new experiences can result in shifts in how individuals understand the world. ${ }^{118}$ In communicating that truth emerges from an open exchange of ideas, he further supported the pragmatic conceptualization of truth as individual, rather than universal. Furthermore, he conceptualized truth as "the only ground up which [our] wishes safely can be carried out."119 Justice Holmes continued within the same passage by describing life as an experiment and that "every year if not every day we have to wager our salvation upon some prophecy based on imperfect knowledge." 20 In conceptualizing life's decisions as "wagers" and by highlighting that knowledge is imperfect, Justice Holmes's dissent relates with his declaration that he is a bettabilitarian and reinforces his rejection of absolutism, which was forged during the Civil War-era and reinforced in his scholarly and legal writings. ${ }^{121}$

Justice Holmes did not understand his dissent to be a departure from his opinions in Schenck, Frohwerk, and Debs. He wrote in Abrams that the previous cases were "rightly decided." 122 He reiterated that in certain contexts, when there is an immediate evil, the government has the right to limit expression. His dissent aligns most clearly with his decisions for the Massachusetts court in the labor

113 Menand, supra note 12, at 427-29.

114 Schenck v. United States, 250 U.S. 616, 620-23 (1919).

115 Novick, supra note 86, at 343.

116 Id. at 346.

117 Abrams v. United States, 250 U.S. 616, 630 (1919) (Holmes, J., dissenting).

118 The Essential Holmes supra note 12, at 7, 107, 115, 117; Holmes, supra note 58, at 40.

119 Abrams, 250 U.S. at 630 (Holmes, J., dissenting).

120 Id.

121 Menand, supra note 12, at 61-62; Holmes, supra note 58, at 41; The Essential Holmes supra note 12 , at 108.

122 Abrams, 250 U.S. at 627-28 (Holmes, J., dissenting). 
union cases in the 1890s and the unpublished dissent in Baltzer, except, this time, he included a theory of the First Amendment. Menand contended that Justice Holmes's focus on the context of the cases remained consistent and that Abrams's actions were simply interpreted as being outside the law's jurisdiction. ${ }^{123}$ Others have argued that the criticism Justice Holmes received during the summer between the Schenck, Frowerk, and Debs cases and Abrams prompted him to reconsider his interpretation of the law. ${ }^{124}$ Regardless of Justice Holmes's reasoning, his dissent in Abrams conveyed central pragmatic conceptualizations regarding the nature of truth and how it operates within individuals' lives. The dissent also signaled a change in his interpretation for free expression protections, as is evident in the final two cases, Gitlow v. New York and United States v. Schwimmer. ${ }^{125}$

\section{G. FINAL DISSENTS}

Unlike the incidents that led to the preceding cases, the conflicts that brought Benjamin Gitlow's and Rosika Schwimmer's cases to the Supreme Court occurred after World War I. Just more than a year after Jacob Abrams and his co-conspirators dumped anti-war leaflets out of New York City buildings, Benjamin Gitlow published his "Left Wing Manifesto." Gitlow's first court appearance in regard to his criminal anarchy charges in New York occurred just days after the Court announced its opinion in Abrams. ${ }^{126}$ Six years later, the Supreme Court invoked reasoning similar to what it had used in Abrams to uphold Gitlow's conviction under the New York state law. ${ }^{127}$ Justice Holmes was the lone dissenter. In his short dissent, he reiterated his clear and present danger test must be utilized in such cases. ${ }^{128} \mathrm{He}$ explained that the majority in Abrams misused his test because there was no "present danger to attempt to overthrow the government." ${ }^{129} \mathrm{He}$ added, using pragmatically related wording, that, "Every idea is an incitement. It offers itself for belief and if believed it is acted on unless some other belief outweighs it or some failure of energy stifles the movement at its birth." ${ }^{130}$ His conclusion regarding beliefs relates closely with the marketplace-of-ideas metaphor he employed in his dissent in Abrams. ${ }^{131}$ Using different terms, he emphasized his understanding that individuals make decisions that are essentially experience-informed bets. Such decisions can change as a

\footnotetext{
123 Menand, supra note 12, at 429.

124 Joseph A. Russomanno, "The Firebrand of My Youth": Holmes, Emerson and Freedom of Expression, 5 Cомм. L. \& PoL'y 33, 34-35 (2000); Fred D. Ragan, Justice Oliver Wendell Holmes, Jr., Zechariah Chafee, Jr., and the Clear and Present Danger Test for Free Speech: First Year, 1919, 58 J. Aм. Hisт. 24, 44 (1971); Bernard Schwartz, Holmes Versus Hand: Clear and Present Danger or Advocacy of Unlawful Action, 1994 SuP. Cт. Rev. 209, 220 (1994).

125268 U.S. 652 (1925); 279 U.S. 644 (1929).

126 Thomas C. Mackey, "They are Positively Dangerous Men": The Lost Court Documents of Benjamin Gitlow and James Larkin Before the New York City Magistrates' Court, 1919, 69 N.Y.U. L. Rev. 421, 425 (1994).

127 Gitlow v. United States, 268 U.S. 652, 661-62 (1925).

128 Id.at 672-73 (Holmes, J., dissenting).

$129 \quad I d$. at 673.

$130 \mathrm{Id}$.

131 Abrams v. United States, 250 U.S. 616 (1919) (Holmes, J., dissenting).
} 
result of shifts in experience. In a letter to a friend, Justice Holmes explained that he understood his discussion of "incitement" in the dissent as his lone original contribution when it is compared with his work in Abrams. ${ }^{132}$ Otherwise, he wrote, indicating his opinion of Gitlow's work, "I regarded my view as simply upholding the right of a donkey to drool." 133

Justice Holmes, nearing his ninetieth birthday, once again dissented four years later in Schwimmer, which revolved around a Hungarian immigrant's contention that the requirement that she, in the process of becoming a United States citizen, agree to be willing to take up arms against enemies of her new country, was unconstitutional. Schwimmer was a pacifist, who contended that a willingness to fight in a war should not be a requirement for citizenship. ${ }^{134}$ Justice Holmes, this time joined by his friend Justice Brandeis, contended that Schwimmer's expression that she was against wars and thought the United States can be improved should not make her ineligible to become a United States citizen. ${ }^{135}$ He continued by drawing his own wartime experiences into his discussion of the need for a free exchange of ideas. Of Schwimmer's pacifism and the necessity of war, he wrote:

I do not share that optimism nor do I think that a philosophic view of the world would regard war as absurd. But most people who have known it regard it with horror, as a last resort, and . . . would welcome any practicable combinations that would increase the power on the side of peace. ${ }^{136}$

Justice Holmes continued the short dissent by accepting that Schwimmer's views might cause unrest and encourage dissatisfaction with the government, but "if there is any principle of the Constitution that more imperatively calls for attachment than any other it is the principle of free thought - not free thought for those who agree with us but freedom of thought that we hate."137

Schwimmer represents Justice Holmes's final statement regarding his understanding of freedom of expression and its necessary limits and protections. He left the Court three years later and died soon after, in 1935. Justice Holmes's legal opinions and scholarly contributions can be encompassed by three ideas in relation to pragmatic philosophy and the nature of truth: (1) His judicial opinions and legal writings consistently communicated an understanding that truth is contingent upon experience. In this sense, his conclusion that the "life of the law has not been logic: it has been experience," in the Common Law in $1881^{138}$ aligns with his contention that "time has upset many fighting faiths" in his dissent in Abrams nearly four decades later. ${ }^{139}$ (2) The opinions and scholarship also support his steadfast stand against absolutism and those who claim ownership of absolute truth. In 1929, just months before penning his dissent in Schwimmer, he wrote "absolute truth is a mirage" as

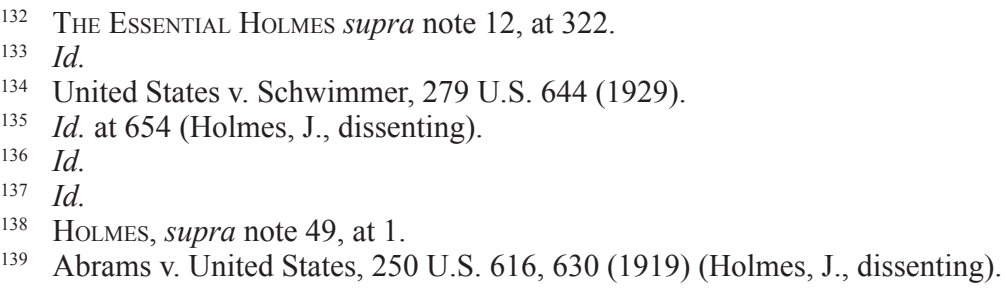


part of a larger discussion of the limits of truth in a letter to Laski. ${ }^{140}$ His distaste regarding those who espoused absolute beliefs was evident in his comparison of Gitlow's work to a "donkey's drool"141 or that Eugene Debs might have "split his guts without my interfering with him." ${ }^{142}$ Furthermore, in wording that appears influenced by his experiences in the Civil War, he espoused in Natural Law that, "Certitude is not the test of certainty. We have been cock-sure of many things that were not so." 143 Such perspectives also align with Justice Holmes's considering himself a bettabilitarian. He believed there was no absolute truth, and that experience drives people's perspectives regarding the world around them. Within such thinking, the best an individual can do is bet, using incomplete knowledge, when making a decision. ${ }^{144}$ (3) Finally, Justice Holmes emphasized that the true meaning of an expression is contextual. His contention regarding the importance of circumstance in deciding the freedom of expression cases, as well as Massachusetts state-court opinions, was that the circumstances surrounding a case were what should decide a case. This was his argument when he was approached by Judge Hand in 1919, that it was not the words or actions of those involved in the cases, so much as the circumstances in which those words and actions took place. ${ }^{145}$ The differing outcomes between Schenck, Frohwerk, and Debs from the spring of 1919 and Abrams, Gitlow, and Schwimmer in the terms that followed are only logically tied together in regard to Justice Holmes's assertion that the context of the expression in question must be the central determining factor. In Schenck, he emphasized that the First Amendment might have protected the socialist party members' actions at other times, when the nation was not at war. ${ }^{146}$ The clear and present danger test introduced by Justice Holmes in Schenck is, in itself, primarily a context-based test because it focuses not on the speaker's words or actions, but on the potential for the words or actions to result in violence toward the government. Justice Holmes's context-based approach can be seen in his reasoning in Plant v. Woods while he was chief justice of the Massachusetts Supreme Judicial Court. In his dissent, he emphasized that the workers went on strike in search of better wages, rather than to damage the business. ${ }^{147} \mathrm{Such}$ a perspective aligns with Justice Holmes's own personal belief against absolutism. He did not believe in a universal legal method for resolving cases. ${ }^{148}$

\section{Truth AND the Court After Holmes}

Substantially catalyzed by external pressures, primarily the Great Depression and Franklin Roosevelt's New Deal legislation, the Court in the years that followed

\footnotetext{
The Essential Holmes supra note 12, at 107.

Id. at 322 .

Id. at 316.

Holmes, supra note 58, at 41.

144 See also Abrams v. United States, 250 U.S. 616, 630 (1919) (Holmes, J., dissenting). In this passage, he wrote, "Life is an experiment. Every year if not every day we have to wager our salvation upon. . . imperfect knowledge."

145 Menand, supra note 12, at 427-29.

146 Schenck v. United States, 249 U.S. 47, 52 (1919).

147176 Mass. 492, 504 (Mass. 1900) (Holmes, C. J., dissenting).

148 See generally, Holmes, supra note 58.
} 
Justice Holmes's retirement shifted its attention toward the relationship between government and the individual. ${ }^{149}$ Supreme Court historian Robert McCloskey contended that historical pressures essentially ended the Court's focus on free enterprise, prompting it to find a new direction. ${ }^{150}$ The shift in focus to individual rights, which occurred both within the Court and more generally in society as a whole beginning in the post-World War II years, instituted a movement away from the pragmatic thinking that had developed during a time period that roughly aligned with the progressive era. ${ }^{151}$ With Justice Holmes, James and Peirce gone, society's champions of pragmatism were fading. ${ }^{152}$ Dewey retired from Columbia in 1930, but carried the torch of progressive-era pragmatism onward as he continued to develop and share his philosophy through books and lectures until his death in 1952. Ultimately, James's and Dewey's disciples, the next generation of pragmatists, were either drawn away from pragmatism to other fields, marginalized because their views drew them into socialistic circles during an era of fierce backlash against such groups, or motivated to draw pragmatism away from its communal and democratic moorings. ${ }^{153}$

While pragmatism faded from the nation's judicial and philosophical conversation, the Court's jurisprudence regarding freedom of expression continued to develop. Since Justice Holmes's departure and pragmatism's fade from the nation's discourse more broadly, hundreds of cases have challenged justices to wrestle with First Amendment questions relating to truth. ${ }^{154}$ Since it is not possible to examine all, or even a substantial number of these cases here, this analysis employed Altheide's method of "progressive theoretical sampling," which emphasizes selecting materials based on an evolving understanding of the topic of the study. ${ }^{155}$ First, the twenty decisions in which the Court used the word "truth" the most times in examining a First Amendment-related issue were identified using a WestlawNext search. ${ }^{156}$ Each of the twenty cases identified in the search were examined. Fourteen of the cases dealt with defamation claims and a majority of the cases were decided in the 1960s and 70s. With the analysis's focus on identifying ways justices have articulated their conceptualizations of truth, the number of defamation cases used was limited, so it would be possible to examine a greater diversity of types of legal questions the Court faced. Similarly, the question is not

149 Robert G. McCloskey, The American Supreme Court 121 (2010). See also John B. Gates, The American Supreme Court and Electoral Realignment, 8 Soc. SCI. HIst. 267, 267-268 (1984). Gates examined the influence of "partisan realignments" on the Court's actions. The start of the New Deal era, which occurred just after Justice Holmes's retirement, is understood by scholars as the clearest example of partisan realignment.

$150 \quad I d$.

151 Menand, supra note 12, at 437-38.

152 Peirce died in 1914.

153 Cornel West, The American Evasion of Philosophy 112-13 (1989); Hollinger \& Depew, Pragmatism: From Progessivism to Postmodernism xv (1995).

154 A LexisNexis Academic search for all of the cases after the 1932 term (Justice Holmes's final term) that include the words "truth" and "First Amendment," resulted in 372 results.

155 Altheide, supra note 19, at 23-44.

156 The cases were identified by conducting a search in the WestlawNext database for all the cases dealing with the First Amendment and the word "truth." The cases were ranked based on the number of times justices used the word "truth" in the case's opinions. 
date-specific, with the only requirement being that the cases occurred after Justice Holmes's retirement. ${ }^{157}$ For this reason, the cases selected represent a variety of years. Using these criteria, six cases were selected: Pennekamp v. Florida (1946), ${ }^{158}$ Beauharnais v. Illinois (1952), ${ }^{159}$ New York Times v. Sullivan (1964), ${ }^{160}$ Cox v. Cohn (1975), ${ }^{161}$ Philadelphia Newspapers v. Hepps (1986), ${ }^{162}$ United States v. Alvarez (2012). ${ }^{163}$ Among the defamation cases, Sullivan was chosen because of its central role in defamation law. Hepps, a second defamation case, was selected because it challenged justices to consider a truth-related question that was substantially different than those that immediately followed Sullivan and was decided in the 1980 s, a decade in which few cases arose in the search. The remaining cases were chosen because they each challenged the Court to consider truth within the contexts of different areas of freedom-of-expression-related law and helped provide a broad representation of years. Before drawing central understandings regarding the Court's conceptualization of the nature of truth from the discourse put forth in these cases, the primary facts, questions, ideas, and overall outcomes are briefly outlined.

\section{A. PENNEKAMP V. FLORIDA}

In Pennekamp, in 1946, the Court overturned a Florida Supreme Court decision to uphold contempt charges against editors at the Miami Herald. The charges stemmed from editorials the criticized Dade County judges' decisions. ${ }^{164}$ The editorials contended that the judges were favoring certain groups in their efforts to "block, thwart, hinder, embarrass and nullify prosecution." 165 The editorials named judges who the authors believed were making rulings that did not benefit the community and identified recent rulings as examples of such decisions. Among the Court's primary considerations within the case were whether the criticisms amounted to a "clear and present danger" to the area's judicial processes and whether the editorials' inclusions of incomplete truths and assumptions deprived the defendant of First Amendment protection. ${ }^{166}$ In regard to the truthfulness of the messages, the justices contended that the editorials distorted their actions and conveyed only halftruths in many instances. ${ }^{167}$ Justice Stanley Reed, writing for the Court, constructed much of the opinion around the conclusion that the words in the editorials, despite the incomplete information that was communicated, did not represent a clear and present danger, thus drawing substantially from the test Justice Holmes fashioned in Schenck and that was taken up by the Court in the sedition cases that followed. ${ }^{168}$

\footnotetext{
157 Though the search encompassed all of the Supreme Court's rulings, none of the cases that appeared in the search were from Justice Holmes's time on the Court.

158328 U.S. 331 (1946).

343 U.S. 250 (1952).

376 U.S. 254 (1964).

420 U.S. 469 (1975).

475 U.S. 767 (1986).

132 S. Ct. 2537 (2012).

Pennekamp v. Florida, 328 U.S. 331, 349-350 (1946).

$I d$. at 339 (quoting one of the editorials, which is included within the opinion).

Id. at 334.

Pennekamp, 328 U.S. at 367 (Frankfurter, J., concurring).

168 Schenck v. United States, 249 U.S.47, 52 (1919).
} 
He ended the opinion, for example, by stating, "We conclude that the danger under this record to fair judicial administration has not the clearness and immediacy necessary to close the door of permissible public comment." 169

Justice Felix Frankfurter, a friend of Justice Holmes with a similar judicial philosophy, wrote a concurring opinion that criticized the Court's use of the clear and present danger test in the case. ${ }^{170}$ Despite an outcome that supported freedom of expression, Justice Frankfurter was uncomfortable with the Court's reasoning. He contended that Justice Holmes did not intend the test to be used in an absolutist sense, nor was it created to limit abstract criticisms. ${ }^{171} \mathrm{He}$ explained that, "It does an ill-service to the author of the most quoted judicial phrases regarding freedom of speech, to make him the victim of a tendency which he fought all his life, whereby phrases are made to do service for critical analysis."172 Justice Frankfurter's opinion, which was longer than that of the Court, ${ }^{173}$ continued by emphasizing the importance of freedom of expression to a free society, thus reinforcing Justice Holmes's rather pragmatic assumption, also supported in James's and Dewey's philosophies, that freedom of expression must be understood as a social, rather than an individual, freedom. ${ }^{174}$

\section{B. BEAUHARNAIS V. ILLINOIS}

Six years after Pennekamp, Justice Frankfurter wrote the Court's opinion in a case that upheld an Illinois law criminalizing the expression of ideas that were disparaging toward certain racial or religious groups. ${ }^{175}$ The justices were deeply divided in the case, with the five-to-four ruling producing four dissenting opinions. The overall decision to uphold the law and Justice Frankfurter's efforts to rationalize the creation of a broadly defined form of "group libel" particularly drew the ire of Justices Hugo Black and William O. Douglas, who wrote separate dissents.

Joseph Beauharnais, who was president of the White Circle League of America in Chicago, was convicted and fined $\$ 200$ for violating state law ${ }^{176}$ by

169 Pennekamp, 328 U.S. at 350.

170 Luban, supra note 80, at 451; The Essential Holmes supra note 12, at 14.

171 Pennekamp, 328 U.S. at 351-352 (Frankfurter, J., concurring).

172 Id. at 352.

173 Justice Reed's opinion for the Court was seventeen pages (pp 333-50). Justice Frankfurter's concurring opinion was nearly twenty pages (p 350-69).

174 Menand, supra note 12, at 432. See also John Dewey, Creative Democracy - The Task Before Us, in The Essential Dewey Vol. 1, 341-42 (Larry A. Hickman \& Thomas M. Alexander, eds., 1998); JAMES, supra note 11, 102-03.

175 Beauharnais v. Illinois, 343 U.S. 250, 251 (1952).

$176 \S 224 \mathrm{a}$ of the Illinois Criminal Code, Ill. Rev. Stat., 1949, c. 38, Div. 1, § 471 provided: It shall be unlawful for any person, firm or corporation to manufacture, sell, or offer for sale, advertise or publish, present or exhibit in any public place in this state any lithograph, moving picture, play, drama or sketch, which publication or exhibition portrays depravity, criminality, unchastity, or lack of virtue of a class of citizens, of any race, color, creed or religion which said publication or exhibition exposes the citizens of any race, color, creed or religion to contempt, derision, or obloquy or which is productive of breach of the peace or riots. . . 
circulating leaflets calling on the Mayor and City Council of Chicago "to halt the further encroachment, harassment and invasion of white people, their property, neighborhoods and persons, by the Negro. . .."177 The leaflet called for "One million self respecting white people in Chicago to unite . . .." and added that "If persuasion and the need to prevent the white race from becoming mongrelized by the negro will not unite us, then the aggressions ... rapes, robberies, knives, guns and marijuana of the negro, surely will." Attached to the leaflet was an application for membership in the White Circle League of America, Inc.

Challenging his conviction Beauharnais argued that the statute violated the liberty of speech and of the press guaranteed as against the States by the Due Process Clause of the Fourteenth Amendment, and was too vague to support a conviction for crime. Upholding the statute and the conviction, Justice Frankfurter, for the Court, explained that the law was created to limit racial and religious violence in a place with a long history of violent unrest. ${ }^{178} \mathrm{He}$ further justified the Court's conclusion by attempting to create a logical, reasoned path from the argument that defamatory attacks on individuals are not protected by the First Amendment, and therefore, similar attacks on defined groups should also be unprotected. He reasoned, "If an utterance directed at an individual may be the object of criminal sanctions, we cannot deny the State the power to punish the same utterance directed at a defined group." ${ }^{179}$ Finally, Justice Frankfurter clouded the Court's opinion by rationalizing the need for state governments to experiment with different solutions to problems and then qualifying the ruling by stating "our finding that the law is not constitutionally objectionable carries no implication of approval of the wisdom of the legislation or its efficacy." 180

Justice Black offered a vigorous dissent, contending that the law was both content-based and that it limited peaceful political speech. ${ }^{181}$ Importantly, in supporting these and other arguments, Justice Black emphasized the importance of individual rights, framing the issue in the case as a matter of the state taking away the individual's right to communicate ideas, as well as the individual's right to receive the ideas communicated by others. The state, to Justice Black, was censoring speech about a matter of substantial public concern, disallowing others' rights to individually receive the ideas. He contended, "No legislature is charged with the duty or vested with the power to decide what public issues Americans can discuss. In a free country that is the individual's choice, not the state's."'182 Justice Black's emphasis on individual, rather than societal, rights extended to his argument against the Court's group-libel-law reasoning. He concluded that the fighting-words doctrine that emerged from Chaplinsky v. New Hampshire ${ }^{183}$ and used by the Court in Beauharnais applied to individual and not group statements ${ }^{184}$ stating that the common-law crime of libel was created to punish "false, malicious, scurrilous charges against individuals, not against huge groups." 185

\footnotetext{
Id. at 252 .

$I d$. at 259 .

Id. at 258 .

Id. at 266-67.

Id. at 267-68 (Black, J., dissenting).

Id. at 270 (Black, J., dissenting).

Chaplinsky v. New Hampshire, 315 U.S. 568 (1942).

4 Beauharnais v. Illinois, 343 U.S. 250, 272-73 (1952) (Black, J., dissenting).

${ }_{85}$ Id. at 272 (Black, J., dissenting).
} 


\section{NeW York Times V. SulLIVAN}

Both Pennekamp and Beauharnais were drawn into Justice William Brennan's opinion for the Court in Sullivan in 1964. The case revolved around a full-page advertisement, titled "Heed Their Rising Voices," which was published in the New York Times as a tool for gathering support, financial and otherwise, for the efforts of the civil rights movement. L.B. Sullivan, the Montgomery, Alabama, commissioner who oversaw the police and other services, contended that the advertisement, though it did not name him or his job title, defamed him because some of the information was incorrectly reported and reflected poorly on the work of those he supervised. ${ }^{186}$ The Court rejected his claims, concluding that to win a defamation claim, a public official must prove actual malice, knowledge that the information was false or a lack of concern regarding its accuracy. ${ }^{187}$

Justice Brennan, who wrote the Court's opinion, rejected both Pennekamp and Beauharnais as guiding precedents in the case. ${ }^{188}$ Instead, he focused extensively, as did Justices Black and Arthur Goldberg in their separate concurring opinions, on the necessity of allowing for some falsity in the nation's discourse in order to protect the flow of information. ${ }^{189}$ Justice Brennan concluded that "debate on public issues should be uninhibited, robust, and wide-open, and that it may well include vehement, caustic, and sometimes unpleasantly sharp attacks on public officials." ${ }^{\prime 90}$ He acknowledged that factual error cannot be avoided in open debate and that regulating speech to avoid such errors would damage discourse in society more broadly. ${ }^{191}$

Justice Black wrote a concurring opinion to indicate that the majority did not go far enough in protecting freedom of expression. He explained that, "Unlike the Court, therefore, I vote to reverse exclusively on the ground that the Times. . . had an absolute, unconditional constitutional right to publish in the Times advertisement their criticisms of the Montgomery agencies and officials." ${ }^{192} \mathrm{He}$ further contended that the country could live without libel lawsuits, but not without the individual right to discuss and comment upon the work of public officials. ${ }^{193}$ Similarly, Justice Goldberg concurred to reinforce the importance that individual citizens and the press should retain their rights to publicly criticize government officials. ${ }^{194}$

\section{Cox V. $\operatorname{CoHN}^{195}$}

Just more than a decade after Sullivan, a substantially remade Court struck down a Georgia law that criminalized the broadcast or publication of the name of a sexual-

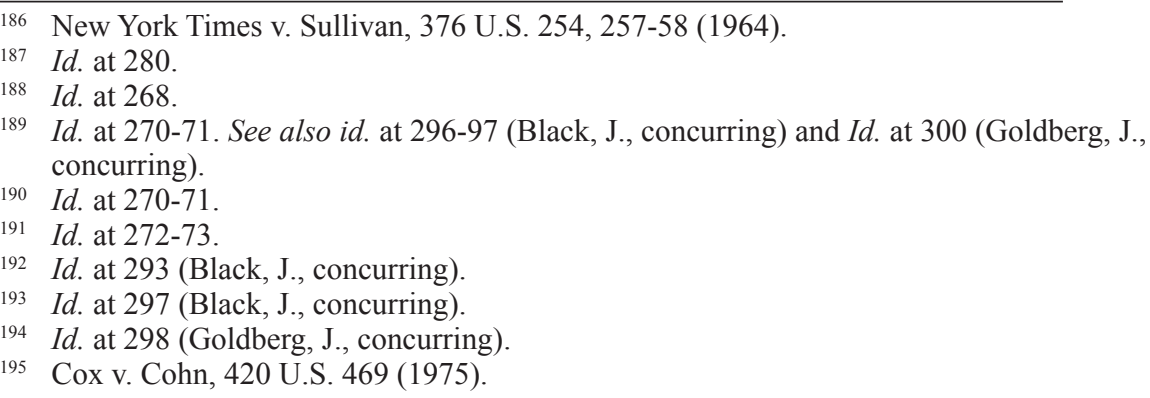


assault victim. ${ }^{196}$ Justice Byron White, one of the three justices who remained from the Sullivan decision, wrote the Court's opinion in the eight-to-one ruling. The case stemmed from a television reporter's coverage of a murder trial in which the victim was sexually assaulted and died as a result of the attack. ${ }^{197}$ The reporter encountered the victim's name while viewing public documents during the murder trial and later reported this during the station's coverage of the trial. Martin Cohn, the victim's father, sued Cox Broadcasting alleging the station violated his right to privacy as protected by the state law. ${ }^{198}$

Justice White emphasized that Cohn's claim did not revolve around any of the established privacy torts. Instead, it sought to penalize the conveyance of true information about a matter of public concern that was legally obtained from publicly available documents. ${ }^{199} \mathrm{He}$ ultimately concluded that the First Amendment protects the press from "liability for truthfully publishing information released to the public in official court records." ${ }^{200}$ Throughout the opinion, Justice White contended that the press must remain free to report information as it preforms its valued service to the public. ${ }^{201}$ Justice Douglas wrote a short concurring opinion to clarify that he agreed with the ruling but did not believe that Justice White went far enough in emphasizing the extent of the First Amendment protections the press enjoys. He contended that, "There is no power on the part of the government to suppress or penalize the publication of "the news of the day." ${ }^{202}$ Finally, Justice William Rehnquist dissented because of questions regarding the Court's jurisdiction on the matter. ${ }^{203}$

\section{E. Philadelphia Newspapers V. Hepps ${ }^{204}$}

Justice Rehnquist again found himself on the dissenting side in the Hepps ruling in 1986. In the five-to-four decision, the Court concluded that a private person seeking damages in a defamation lawsuit must prove that the potentially damaging words were false, thus shifting the burden from the previous common-law understanding that the burden rested on the communicator to prove his or her message was true. ${ }^{205}$ The case arose when a series of stories in the Philadelphia Inquirer indicated that Maurice Hepps, who led a chain of stores in Pennsylvania, had ties to organized crime and used his influence to manipulate government officials. ${ }^{206}$

In the Court's opinion, Justice Sandra Day O'Connor recognized that many expressions of comment cannot be definitively proven to be true or false, which would mean that the plaintiff's burden of proving falsehood would at times

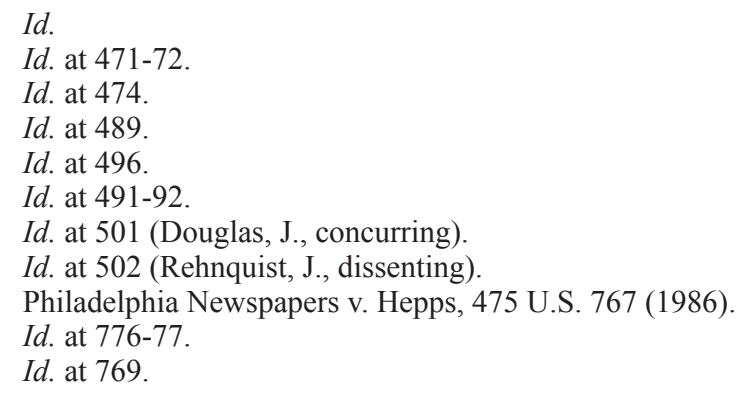


allow untrue and harmful messages to damage the reputations of individuals. ${ }^{207}$ In attempting to balance the considerations between freedom of expression and protecting the reputations of individuals, the Court concluded that "the Constitution requires us to tip them [the scales] in favor of protecting true speech." 208 Justice John Stevens' dissent, which was joined by Justice Rehnquist and two others, focused on the very problems Justice O'Connor examined in deciding to err on the side of freedom of expression and to require plaintiffs to prove falsehood. Justice Stevens contended that "the only publishers who will benefit from today's decision are those who act negligently or maliciously." ${ }^{209}$ He further concluded that some facts cannot be verified or disproven, with the regrettable result that canny individuals may be permitted to destroy the reputations of others by carefully manipulating information in such a way as to be certain the victim could not prove the statements to be false. ${ }^{210}$ Both the Court's opinion and Justice Stevens's dissent ultimately focused on the extent to which individuals could prove statements as being true or false. The justices repeatedly used the terms "true facts," "true speech," and "unprovable facts," for example, as they ultimately disagreed regarding the amount of protection an individual who is harmed by information has when forced to overcome the burden of proving the information or comment about them was false. ${ }^{211}$

\section{F. UNITED STATES V. ALVAREZ ${ }^{212}$}

Xavier Alvarez falsely claimed during a public meeting that he received the Congressional Medal of Honor and was charged with violating the Stolen Valor Act.. ${ }^{213}$ Alvarez contended that the law violated his First Amendment rights and, in a six-three decision in 2012, the Court agreed, striking down the law. The Court's opinion and Justice Alito's dissent diverged regarding whether false statements should receive First Amendment protection and if the law was overly broad in the types of speech it proscribed. Justice Kennedy, writing for the Court, found the "quite unprecedented reach of the statute puts it in conflict with the First Amendment. . . . The statute seeks to control and suppress all false statements on this one subject in almost limitless times and settings." 214 His primary concern regarding the law's breadth was that in the effort to halt untrue speech about military honors, the law would chill truthful speech. Citing Justice Holmes's marketplace metaphor from Abrams $^{215}$ and the Court's conclusion that false statements are inevitable in free debate from Sullivan, ${ }^{216}$ Justice Kennedy contended that the law posed too great a danger to freedom of expression.

Id. at $776-77$.

Id. at 776 .

Id. at 780 (Stevens, J., dissenting).

Id. at 785-86 (Stevens, J., dissenting).

211 See id. at 776, Id. at 778, and $I d$. at 785 (Stevens, J., dissenting), for examples.

212 United States v. Alvarez, 132 S. Ct. 2537, 2537 (2012).

213 Id.

214 Id. at 2547.

215 Id. at 2550 (citing Abrams v. United States, 250 U.S. 616, 630 (1919) (Holmes, J., dissenting)).

216 Id. at 2544 (citing New York Times v. Sullivan, 376 U.S. 254, 271 (1964)). 
Justice Alito, in dissent, presented a substantially different interpretation of the law in question. He concluded the law "applies to only a narrow category of false representations of objective facts that can almost always be proved or disproved with near certainty." ${ }^{217}$ Furthermore, he distinguished his definition of false speech from Justice Kennedy's, emphasizing that the First Amendment does not protect false statements of fact because they do not contribute to free debate in society. ${ }^{218}$ He compared such statements to disagreeable ones made about subjective matters, such as philosophy or within the social sciences, finding that in certain areas of discussion "there is no such thing as truth or falsity" because "the truth is impossible to ascertain." ${ }^{219}$ Thus, Justice Alito understood the law to be narrowly tailored because in his conceptualization, the speech it restricted was the type of false expression that contributes nothing of value to public discourse.

\section{ANALYSIS}

The Court's opinions in the cases outlined in the preceding section, when drawn together, represent a decades-long dialogue between the justices regarding the nature of truth as it relates to the protection of freedom of expression in a democratic society. The cases were analyzed using qualitative document analysis methodology, which in this stage emphasized analyzing data by conducting repeated readings of the cases, sorting and comparing information, and searching through the documents. ${ }^{220}$ Furthermore, it included comparing and contrasting extremes and noteworthy differences, summarizing findings, and placing the findings within a broader interpretation. ${ }^{221}$ The method focuses on moving beyond identifying what is written in a text. Instead, analysis must be "oriented to documenting and understanding the communication of meaning, as well as verifying theoretical relationships." 222 After analyzing six of the cases in which the Court most extensively examined truth as it relates to freedom of expression, and in which justices ultimately constructed rationalizations for their understandings of truth, three primary themes emerged regarding how justices have understood truth. In particular, the justices conceptualized truth in terms of the value of free debate as a public good in a democratic society, its malleability as something that is provisional and contingent in nature, and its formation as a consequence of communication processes in society.

\section{A. The Value of Free Debate as a Public Good}

The justices' discourse in the cases examined consistently communicated an understanding that the possible truth or falsity of an idea or expression was a matter

\footnotetext{
Id. at 2557 (Alito, J., dissenting).

$I d$. at 2563 (Alito, J., dissenting).

Id. at 2564 (Alito, J., dissenting).

Altheide, supra note 19, at 23-44.

Id.

Id. at 16.
} 
to be considered in relation to the value of free debate as a public good or contribution to democratic values. Such an understanding was substantially communicated in Sullivan, in which Justice Brennan identified the questions that surrounded the form of communication - an advertisement -223 and the factual errors in the message, as concerns in the case. The Court's discourse conveyed the idea that the form of the message and the errors were not destructive to the case, in this instance, because the expression in question addressed "a movement whose existence and objectives are matters of the highest public interest." 224 Later in the opinion, Justice Brennan drew "good motives and belief in truth" together in his discussion of defamation law. 225 He returned to the form and content of the message later in the opinion, concluding, "the present advertisement, as an expression of grievance and protest on one of the major public issues of our time, would seem clearly to quality for the constitutional protection. The question is whether it forfeits that protection by the falsity of some of its factual statements." ${ }^{226}$ Ultimately, the Court, largely basing its rationale on the contribution of the message as a matter of public discourse - its perceived goodness and value - concluded the format and false statements were not enough to make the New York Times liable in the case.

Similarly, in Beauharnais, Justice Frankfurter drew discussion of whether or not the ideas communicated by the plaintiff were made with "good motives" or could be regarded as "utterances as fair comment" into the opinion for the Court. ${ }^{227} \mathrm{He}$ concluded his opinion for the Court by emphasizing that the truth of the statements that are made should often be considered alongside the author's intent and whether or not the person had "justifiable ends." 228 Thus, to Justice Frankfurter, at least in a defamation case that occurred twelve years before New York Times v. Sullivan was decided in 1964, the meaning and the intent of the message, its contributory aspects, were a crucial part of the case's considerations. Justice Black, while he dissented, largely constructed his opinion in the case on the basis that Beauharnais's ideas were a matter of public concern. ${ }^{229}$ Therefore, once again, the social value of the ideas was placed alongside the consideration of the value of truth and falsity in discourse. These considerations by the justices in this case further reinforce the broader narrative that justices understand and evaluate truth and falsity by reference to perceptions of public good or value in a democratic society. The Court in Cox, a case which posed a substantially different question from that considered in Sullivan and Beauharnais, found the truthfulness of the message was not in question, but the Court still conceptualized the issue of accuracy in terms of the statement's value as a public good. The Court identified the question before it as revolving around the "great responsibility" the news media carry in reporting "fully and accurately the proceedings of the government,

\footnotetext{
223 Advertising was not protected by the First Amendment in 1964. It would not receive such protection until the mid-1970s. See Bigelow v. Virginia, 421 U.S. 809 (1975) and Virginia Pharmacy Board v. Virginia Consumer Council, 425 U.S. 748 (1976).

224 New York Times v. Sullivan, 376 U.S. 254, 266 (1964).

225 Id. at 267.

226 Id. at 271.

227 Beauharnais v. Illinois, 343 U.S. 250, 264-65 (1952).

228 Id.

229 Id. at 270 and 272 (Black, J., dissenting).
} 
government officials, and documents open to the public." ${ }^{230}$ Throughout the Court's opinion, the importance of the media making "truthful information available on the public record" was repeated, further communicating the understanding that the extent of a statement's truth or falsity should be evaluated in relation with the public-good value of free debate.. ${ }^{231}$

The theme was communicated from a different perspective in Hepps and Alvarez, which dealt substantially with the extent to which false statements can contribute value to democratic discourse or the "public good." Justice Kennedy, writing for the Court in Alvarez, contended that false speech could, in some instances, be a public good. ${ }^{232} \mathrm{He}$ explained that such false statements can "avoid embarrassment, protect privacy, shield a person from prejudice, provide the sick with comfort, or preserve a child's innocence." ${ }^{233}$ Thus, Justice Kennedy reasoned that false statements, while they receive less protection than true statements, must still be evaluated based on the extent to which they benefit others. While Justice Alito dissented in the case, his reasoning appeared to align with Justice Kennedy's. He explained that the misinformation Alvarez was involved in spreading was intentionally false and that it served no public good. ${ }^{234}$ Thus, the false information served no public good. Justice Alito emphasized that free speech "does not protect false factual statements that inflict real harm and serve no legitimate interest." 235 Similarly, in Hepps, Justice Stevens reasoned in his dissent that false speech does not contribute to the public good and therefore should not be protected. He wrote that, "while deliberate or inadvertent libels vilify private personages, they contribute little to the marketplace of ideas." ${ }^{236} \mathrm{He}$ further concluded that some speech is "beyond the constitutional pale," 237 reinforcing the idea, which was primarily discussed in Sullivan, Beauharnais, and Cox, that truth and good intent are a social good and are intertwined as considerations by the Court. For these reasons, it must be understood that false speech is least likely to receive First Amendment protection when it cannot be understood as a social good. Reciprocally, false information can at times be protected if it can be attached to some form of public social benefit.

\section{B.The Provisional and Contingent Nature of "Truth"}

In the cases examined, it is clear that the justices consistently conceptualized knowledge of truth or falsity as something that was contingent upon the reception of further information. In this sense, issues of truth and falsity were understood as being, at the same time, static and dynamic. Truth could be static to the extent that the justices understood a matter to be universal reliable and not open to challenge. At the same time, however, the Court clearly recognized that new knowledge, if attainable, could transform truth to untruth, untruth to truth, or a provisional truth

\footnotetext{
Cox v. Cohn, 420 U.S. 469, 491-92 (1975).

Id. at $495-497$.

United States v. Alvarez, 132 S. Ct. 2537, 2553 (2012).

$I d$.

Id. at 2557 (Alito, J., dissenting).

Id.

236 Philadelphia Newspapers v. Hepps, 475 U.S. 767, 782 (1986) (Stevens, J., dissenting).

237 Id.
} 
or falsity to something more concrete. Such a challenging, contingent dynamic between fully accepting truths or falsities as being absolute and leaving room for them to be reassessed was a central ingredient within the conflicting understandings communicated in the narratives regarding the nature of truth. The theme in this regard was most substantially represented in Pennekamp, in which justices continuously accepted "the truth" that was available as concrete, while recognizing that the "whole" or "full" truth might not yet be known. The Court accepted "the facts stated in the editorials were correct, ${ }^{\prime 238}$ and relied heavily upon that understanding in its decision to reverse the lower-court's ruling against the newspaper. ${ }^{239}$ The truth as it was known, was sufficiently reliable to come to a conclusion in the case. Such a conclusion, however, did not preempt extensive discussion by the justices regarding the likely existence of more information, more knowledge, that would have influenced how the editorials were received and, potentially, the ruling itself. Justice Reed, writing for the Court conceded, "it is clear that the full truth. . . . was not published." 240 In his concurring opinion, Justice Wiley Rutledge reiterated that all of the information was not made available in the editorials, but recognized the speed at which reporting is done, positing, "There must be some room for misstatement of fact, as well as misjudgment, if the press and others are to function as critical agencies in our democracy." 241

The Court's rulings in the defamation cases, Sullivan and Hepps, conveyed a similar understanding of truth and falsity as being provisional and contingent upon receipt of further information. In Sullivan, the actual malice standard at the heart of the precedent pivots upon an assumption that an inquiry must be made into whether the information was true or false and whether or not the communicator cared or was aware of the message's truth or falsity. ${ }^{242}$ In recognizing Alabama's libel law in the passage before discussing the actual malice standard, Justice Brennan wrote, "even though it is believed to be true and even though it is in fact true, because of doubt whether it can be proved in court or fear of the expense of having to do so," speech might be limited. ${ }^{243}$ In such a passage, the broad understanding of the inherent malleability of the issue of truth as being both fixed and contingent can clearly be seen.

Similarly, in Hepps, the Court repeatedly concluded that expressions must be "proven" or "shown" to be true or false, thus communicating the understanding that a decision on truth or falsity was contingent on more information. ${ }^{244}$ The Hepps case, however, added the concern that some expressions cannot be proven true or false. A central point of contention between the Court's majority and the dissent was in regard to the ramifications that potentially defamatory statements that could not be proven true or false would have on plaintiffs and defendants in such cases. Justice O'Connor, writing for the Court, concluded, "There will always be instances when the factfinding process will be unable to resolve conclusively

238 Pennekamp v. Florida, 328 U.S. 331, 340 (1946).

239 Id. at 349-50.

240 Id. at 344.

241 Id. at 372 (Rutledge, J., concurring).

242 New York Times v. Sullivan, 376 U.S. 254, 279-80 (1964).

243 Id. at 279.

244 Philadelphia Newspapers v. Hepps, 475 U.S. 767, 776 (1986). 
whether the speech is true or false." ${ }^{245}$ The Court recognized this concern, and found that the assumed burden should be on the plaintiff, not the speaker. Justice Stevens, dissenting, contended that the existence of "unprovable facts" meant that placing the burden of proving falsity on the plaintiff would mean malicious gossip and character assassination would be protected by the First Amendment. ${ }^{246}$ Despite the justices' disagreements in the case, the Court's concern about the fact that some expressions can neither be true nor false in Hepps contributes to the broader theme that justices conceptualized truth as being contingent and provisional in these cases. To consider this conclusion in another way, if an expression cannot be proven true or false, it cannot be conceptualized as being objective and universal to all. Instead, it is best classified as being provisional and contingent.

Finally, in Alvarez, justices articulated an understanding of truth and falsity as being divisible into two groups: statements of fact and more abstract statements dealing with intangible ideas, such as "philosophy, religion, history, the social sciences, the arts and the like." 247 Justice Breyer, concurring with the Court's conclusion that the law violated the First Amendment, concluded, "the dangers of suppressing valuable ideas are lower where, as here, the regulations concern false statements about easily verifiable facts." ${ }^{248}$ In essence, Justice Breyer emphasized that while there is significant danger in limiting expression in many areas where truth is not necessarily fact-based, such as in philosophical or religious discussions, that was not the problem in the present case, because the information was easily checked and contributed little to society. Justice Alito, in a dissent that defended the law in question, also recognized concerns about limiting potentially false speech. Like Justice Breyer, he indicated there are simply areas where the truth cannot be agreed upon and speech must, therefore, be given "a degree of instrumental constitutional protection." ${ }^{249}$ In regard to the less-clear areas, he explained, "The point is not that there is no such thing as truth or falsity in these areas, or that truth is always impossible to ascertain, but rather it is perilous to permit the state to be arbiter of truth. ${ }^{250}$ In stating as much, Justice Alito, along with the justices in the other cases, contributed to general conclusion that justices regard matters of truth and falsity as being provisional and contingent in the broad sense that allowance should be made for the possibility that new information could change the perspective from which they are viewed.

\section{Communication as a Social Process}

The set of cases examined above most consistently communicated an understanding by the justices that the production of what is regarded as truth is a social process and an important component of the way in which knowledge can be generated in a democratic society. The conclusion then has to be that more speech, rather

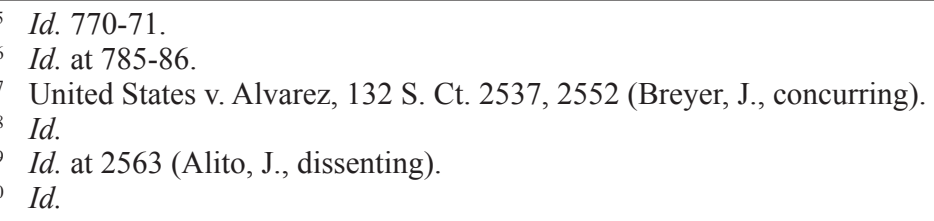


than less, would be the best way to ensure that such a process can flourish. ${ }^{251}$ In Pennekamp and Hepps, the Court weighed freedom of expression against the value of a respected judiciary and the reputation rights of citizens, respectively. Both amount to important societal considerations. In both instances, the Court erred on the side of more speech, and communicated an understanding in rationalizing such decisions that more speech would be the best road to fostering the discovery of truth. In Hepps, Justice O'Connor used the metaphor of a set of scales, which required balancing the protection of the reputations of private individuals against the democratic value of freedom of expression. She concluded the Court must "tip [the scales] in favor of protecting free speech." 252 The Court in Pennekamp articulated a concern for protecting the reputation of the judicial process against any potential adverse impact from media reports that criticized the courts or negatively reported on certain cases. In its decision, the Court concluded, "We think the specific freedom of public comment should weigh heavily against a possible tendency to influence pending cases. Freedom of discussion should be given the widest range." ${ }^{253}$ The justices' conclusions, and their rationalizations all support the view that the Court conceptualizes the formation of truth and knowledge as a social process that in a democracy should require the fewest limitations possible.

The conceptualization of truth formation as a societal process that requires substantial freedom for the communication of ideas was discussed in the Sullivan and Beauharnais cases in terms of the harm such speech might realize. In his dissent in Beauharnais, Justice Douglas allowed that debate on important issues could at times become emotional and destructive. He concluded, however, that the authors of the Bill of Rights were aware of the dangers in ideas, and when faced with a question of more speech or control of speech, "they chose liberty." ${ }^{254}$ Similarly, Justice Brennan in the Court's opinion in Sullivan enumerated the ways in which speech could reach public officials, recognizing that it could be "vehement, caustic, and sometimes unpleasantly sharp." ${ }^{255}$ Later in the opinion, he wrote that limitations on speech dampen "the vigor and limit the variety of public debate." 256 In a different type of case, in Cox, the Court rationalized its conclusion that the publication of public records cannot be criminalized by contending, "the citizenry is the final judge of the proper conduct of public business." 257

Finally, in Alvarez and Hepps, the justices recognized that despite the value of encouraging the processes of truth and knowledge formation, it is sometimes the case that speech which is not true must be protected. Justice Kennedy, in the Court's opinion in Alvarez, posited that the Stolen Valor Act risked suppressing "all false statements on this one subject in almost limitless times and settings."258

\footnotetext{
251 Such a conclusion aligns significantly with Justice Louis Brandeis's contention in his concurring opinion in Whitney v. California, 274 U.S. 357, 377 (1927) that "If there be time to expose through discussion the falsehood and fallacies, to avert the evil by the processes of education, the remedy to be applied is more speech, not enforced silence."

252 Philadelphia Newspapers v. Hepps, 475 U.S. 767, 777 (1986).

253 Pennekamp v. Florida, 328 U.S. 331, 347 (1946).

254 Beauharnais v. Illinois, 343 U.S. 250, 287 (1952) (Douglas, J., dissenting).

255 New York Times v. Sullivan, 376 U.S. 254, 270 (1964).

$256 I d$. at 279.

257 Cox v. Cohn, 420 U.S. 469, 495 (1975).

258 United States v. Alvarez, 132 S. Ct. 2537, 2547 (2012).
} 
contending that falsity, in itself, does not automatically place speech outside of First Amendment protection. ${ }^{259}$ Despite substantially disagreeing with the Court, Justice Alito recognized that the Court has historically protected some false speech because limiting it would endanger true speech. He contended, "all of these proof requirements inevitably have the effect of bringing some false factual statements within the protection of the First Amendment, but this is justified in order to prevent the chilling of other valuable speech." ${ }^{260}$ Similarly, in Hepps, the Court recognized that a standard that placed the burden of proving falsity on the plaintiff, rather requiring the defendant to prove truth would incidentally allow for the protection of false statements. ${ }^{261}$

\section{Proposing a Unified Conceptualization of Truth}

The goal of this article has been to identify how the Supreme Court has conceptualized truth and, with this information and conceptual building blocks from pragmatic thought and Justice Holmes's legal, scholarly, and personal writings, to construct a unified conceptualization of truth that can be applied in freedom-of-expressionrelated cases. This goal was partially accomplished in the preceding section by identifying the Court's consistent approach to questions of truth in judgements that they make concerning the value of free speech as a public good in a democratic society, their understandings of the provisional and contingent nature of matters of truth and falsity, and the role of societal communication processes in shaping the way these matters are understood. Constructing such a conceptualization regarding the nature of truth is about externalizing an internal process and is thus different to building a test for obscenity or time, place, and manner restrictions. These factors, however, do not make such an effort less valuable. How justices conceptualize the nature of truth can influence their decisions in freedom-of-expression cases, which ultimately bear upon the crucial flow of information in a democratic society. The internal nature of how truth is understood, however, requires that the unifying model also be focused on more internal, but potentially shared, recognitions regarding the forces at play regarding how truth is understood.

The understandings detected within the Court's cases, in conjunction with the insights of pragmatic theory and the work of Justice Holmes indicate that a unifying conceptualization regarding the nature of truth must begin with the recognition that truth is a process. In this regard, the justices have communicated the assumption that ideas and information are to be evaluated by reference to the values of public good and democratic discourse and that the formation of truth is a societal process. ${ }^{262}$ Justices also understand the inherent malleability of the concept in the sense that matters of truth can only be evaluated by reference to what is known and that new information might ultimately displace current understandings. ${ }^{263}$ Thus, in freedom-

\footnotetext{
Id. at 2545 .

Id. at 2563-64 (Alito, J., dissenting).

Philadelphia Newspapers v. Hepps, 475 U.S. 767, 776-77 (1986).

62 See New York Times v. Sullivan, 376 U.S. 254, 266 (1964); Philadelphia Newspapers v. Hepps, 475 U.S. 767, 777 (1986) for example.

263 See Pennekamp v. Florida, 328 U.S. 331, 340 (1946); United States v. Alvarez, 132 S.
} 
of-expression cases, the Justices have evaluated the facts they had before them, but often recognized that additional information might have changed the Court's conclusion. In this way there are close similarities with the work of James as we saw earlier. ${ }^{264}$ James, in his exposition of pragmatism, indicated that truth "is simply a collective name for verification processes ${ }^{265}$ and compared the creation of truth to amassing of wealth or the maintenance of health, ${ }^{266}$ So too Justice Holmes referred to absolute truth as a "mirage" and highlighted its contingent nature in a variety of texts. ${ }^{267}$ In "Natural Law", he characterized truth as "the system of my (intellectual) limitations," indicating a recognition that his ability to identify something as truthful is contingent upon a series of factors that he can rely upon, but never to the extent that he can be certain of his conclusions. ${ }^{268}$ Thus, he identified truth as something he and others make to create order in their worlds. ${ }^{269}$

A second step calls for a recognition of truth as being "experience-funded." 270 The Court's freedom of speech discourse clearly recognized truth as the result of conclusions based on what was known and the product of societal processes but did not explicitly characterize conclusions regarding truth as being the result of experience. ${ }^{271}$ Justice Holmes and James, however, understood experience as the crucial ingredient in the making of truth. James explained that individuals use their experiences, which form how they understand the world around them, to determine what is true, explaining that, "We receive...the block of marble, but we carve the statue ourselves"272 Furthermore, as individuals who have established firm convictions concerning what is true and false are later called upon to internalize new experiences, their understandings can be transformed. Justice Holmes famously concluded that the "life of the law has not been logic: it has been experience." 273 He furthermore consistently referred to his experiences in the Civil War as having changed his outlook. ${ }^{274}$ Finally, he identified himself as a bettabilitarian, indicating that individuals cannot know the absolute truth, so they bet using their experiences as their guide to deciding what is true and what is not. ${ }^{275}$ Such a perspective was characterized in his formulation of the marketplace-of-ideas metaphor, where he concluded that, "We wager our salvation upon some prophecy based on imperfect knowledge." 276

Ct. 2537, 2552 (Breyer, J., concurring) for example.

264 See notes 38-40 and accompanying text on pp. 9-11.

265 JAMES, supra note 11, at 104.

266 Id.

267 HoLmes, supra note 12, at 107.

268 Holmes, supra note 58, at 40.

269 Id. See also discussion supra pages 12-14.

270 JAMES, supra note 11, at 107.

271 Pennekamp v. Florida, 328 U.S. 331, 347 (1946); Beauharnais v. Illinois, 343 U.S. 250, 287 (1952) (Douglas, J., dissenting); Philadelphia Newspapers v. Hepps, 475 U.S. 767, 776 (1986).

272 JAMES, supra note 11, at 117.

273 Holmes, supra note 49, at 1.

274 Holmes, supra note 63, at 11; Holmes, supra note 12, at 73; Holmes, supra note 58, at 41.

275 Holmes supra note 12, at 108; Luban, supra note 80, at 474n.78.

276 Abrams v. United States, 250 U.S. 616, 630 (1919) (Holmes, J., dissenting). 
A third and final theme is that matters of truth should not be understood from absolutist or prejudicial eyes. Such an ingredient aligns with the conclusion that truth should be conceptualized as a process and as something that is experiencefunded. Such an approach draws from key understandings from pragmatic thought, as well as Justice Holmes's scholarly, legal and personal writings. Pragmatic thought emphasizes a necessity to avoid approaching questions and problems using "bad a priori reasons, ... fixed principles, closed systems, and pretended absolutes and origins." 277 Furthermore, James emphasized that "theories become instruments" rather than stringent, unbending rules. ${ }^{278}$ Justice Holmes consistently discounted unbending, absolutist perspectives. ${ }^{279}$ In "Natural Law," for example, he explained that "our best test of truth is a reference to either a present or an imagined future majority in favor of our view." ${ }^{280}$ Menand characterized Justice Holmes and James, as well as Dewey, as understanding democracy as being based on tolerance. He explained, "The political system their philosophy was designed to support was democracy. And democracy, as they understood it, isn't about letting the right people have their say; it's also about letting the wrong people have their say." 281 Finally, such an addition to the model aligns with the theme communicated in the Court's cases that truth is the result of communication processes within society. As was communicated by Justice Holmes, absolutist perspectives are not conducive to the formation of truth in society. The Court in the freedom-of-expression cases analyzed communicated an understanding that more speech, rather than less, was the most likely approach to fostering the discovery of truth. ${ }^{282}$

In conclusion, this proposed unifying conceptualization of the nature of truth calls for the recognition of three substantially related understandings regarding truth: that truth is a process, that it is experience-funded, and that it is not absolute and is best approached without prejudice. Each of the three ingredients relates, at least to some extent, with thematic understandings demonstrated by the Court in previous freedom-of-expression cases, and therefore does not represent a significant departure from justices' traditional approaches to truth. The model, most ideally, does seek, with the help of pragmatic thought and the work of Justice Holmes, to encourage consistent recognition of certain principles regarding truth as justices go about considering its nature in First Amendment cases.

277 JAMES, supra note 11, at 31 .

278 Id. at 32. See also discussion supra pp. 7-11.

279 Holmes, supra note 58, at 40. See also discussion supra pp. 12-14.

280 Id.

281 Menand, supra note 12, at 440.

282 See Philadelphia Newspapers v. Hepps, 475 U.S. 767, 777 (1986) and Pennekamp v. Florida, 328 U.S. 331, 347 (1946), for example. 